\title{
Article \\ Start-Up Ecosystem (StUpEco): A Conceptual Framework and Empirical Research
}

\author{
Christos Ziakis ${ }^{1, *}$, , Maro Vlachopoulou ${ }^{2}(\mathbb{C})$ and Konstantinos Petridis ${ }^{2}$ \\ 1 Department of Economic Sciences, International Hellenic University, 62124 Serres, Greece \\ 2 Department of Applied Informatics, University of Macedonia, 54636 Thessaloniki, Greece; \\ mavla@uom.edu.gr (M.V.); k.petridis@uom.edu.gr (K.P.) \\ * Correspondence: ziakis@gmail.com; Tel.: +30-6937-462999
}

Citation: Ziakis, C.; Vlachopoulou, M.; Petridis, K. Start-Up Ecosystem (StUpEco): A Conceptual Framework and Empirical Research. J. Open Innov. Technol. Mark. Complex. 2022, 8, 35. https://doi.org/10.3390/ joitmc 8010035

Received: 10 January 2022

Accepted: 30 January 2022

Published: 7 February 2022

Publisher's Note: MDPI stays neutral with regard to jurisdictional claims in published maps and institutional affiliations.

Copyright: (C) 2022 by the authors. Licensee MDPI, Basel, Switzerland. This article is an open access article distributed under the terms and conditions of the Creative Commons Attribution (CC BY) license (https:// creativecommons.org/licenses/by/ $4.0 /)$.

\begin{abstract}
Start-up development, success, and sustainability are affected by contextual factors that constitute a regional entrepreneurship ecosystem. Based on previous literature, we propose the conceptual framework Start-Up Ecosystem (StUpEco) that highlights the contextual drivers of a start-up business affected by the entrepreneurial ecosystem entities involved within the quadruple helix model. Furthermore, the proposed framework is tested according to the perceptions of Greek start-uppers through an empirical survey. According to our findings, the start-uppers' motivation is explained mainly through opportunity rather than necessity. The study identifies government issues, such as tax incentives and acceleration of starting procedures, availability of funding opportunities, connectivity of stakeholders, entrepreneurship education, previous start-up experience, incubator support, as well as mentoring, as the most significant issues affecting the successful development of start-ups.
\end{abstract}

Keywords: innovation; quadruple helix; start-up ecosystem; start-ups; open innovation dynamics

\section{Introduction}

Entrepreneurs are found to "spur innovation, speed up structural changes in the economy, introduce new competition and contribute to productivity, job creation and national competitiveness" [1]. Thus, entrepreneurship is critical to socioeconomic growth and prosperity, as it contributes directly to employment by creating new jobs and fostering innovation [2-4]. Innovation has been recognized as a critical factor in economic growth. It has been directly linked to start-up companies that are "human institutions designed to create a new product or service under conditions of extreme uncertainty" [5]. In this respect, the development of start-ups is institutionally supported in most developed countries by simplifying the regulatory framework governing their establishment and operation, creating a favorable investment environment, and building direct interaction with the educational community and other entities of the entrepreneurial start-up ecosystem.

Open innovation is a type of business management strategy for innovation that promotes collaboration with persons and groups outside of a corporation [6]. It is a strategy that allows businesses to stretch their limits further by co-operating with external professionals and firms [7]. In its different forms, culture has always been a significant driver of innovation and plays a critical role in open innovation dynamics. The culture for open innovation dynamics results from interactions among entrepreneurship, intrapreneurship, and organizational entrepreneurship [8]. Its promotion is based on providing a set of factors that make the partnership successful [9].

In this context, entrepreneurial ecosystems have emerged as a popular concept to explain the existence of high-growth entrepreneurship within regions, focusing on the combination of environmental factors that play a role in influencing people's willingness and ability to undertake entrepreneurial activities and facilitating the start-up process. However, the theoretical concept of ecosystems remains underdeveloped, thus making it 
difficult to understand their structure and influence on start-up entrepreneurship. Startup ecosystems are the union of localized cultural outlooks, social networks, investment capital, universities, and active economic policies that create environments supportive of innovation-based business [10]. Due to the financial crisis, rapidly evolving conditions, and diversified consumer needs, the encouragement of start-up entrepreneurship supported by the entities involved in these ecosystems is even more critical, as it is characterized by a high degree of responsiveness and flexibility [11].

Start-ups make a significant contribution to jobs creation in the U.S., since $70 \%$ of new employment is derived from newly established companies [12]. In the EU, startups generate $9.5 \%$ of total GDP [13]. Companies with strong growth dynamics have a particularly positive influence on GDP growth $[14,15]$. At the same time, start-ups promote innovation, speed up institutional change, and boost productivity by introducing new products to the market [16].

In order to successfully influence the rate of new business starts, we must first understand how the start-ups' ecosystem factors impact such rates. Start-ups' competitive advantage depends on a plethora of factors relating to academia, industry, government, and civil society, which constitute the core pillars of the quadruple helix approach. This research aims to study and evaluate the driving factors considered as critical to start-ups' success, as well as to develop a conceptual framework of a StUpEco, thus incorporating entities involved within the quadruple helix model. In order to test and evaluate the proposed framework, a survey was conducted, focusing on the Greek start-up ecosystem. In line with this, education, human resources, governmental interventions, funding, networking, and support opportunities provided by the four pillars of the quadruple helix approach are analyzed based on Greek start-uppers' perceptions. In this study, we proceed to an extended literature review, firstly regarding the evolution of the quadruple helix model as a pillar for innovative entrepreneurship and secondly to determine and examine contextual factors of the start-up ecosystem. The factors can be grouped in the following determinants: education and research (EDU), human capital (HR), finance and funding (FUN), governmental interventions (GOV), business support and connectedness (SUP). By combining the four helices of the quadruple helix model (academia, industry, government, civil society) with the enabling factors of a start-up business, we propose the StUpEco framework; this is a hybrid model where each of the four helices and their entities contribute to each dimension of factors that activate the success of a start-up. The conceptual framework helps to better understand the structure of a start-up ecosystem, as well as the influence of its drivers on the start-ups' competitive advantage.

The proposed conceptual framework (StUpEco) is tested according to the perceptions of Greek start-uppers through an empirical survey. The survey material has been constructed based on the literature review around factors affecting the sustainability of start-ups, as well as the connections of the start-uppers with the entities of the ecosystem. The findings include descriptive statistics regarding the profile of the start-ups, the sources of funding received, and their collaborations with the ecosystem entities. In order to draw further conclusions through analyzing the current state of start-ups in Greece, crosstabulations are formed; the competitive advantages of the start-ups, as highlighted by the start-uppers, are analyzed in comparison to the incentives of business creation because of necessity and opportunity. The second part of the findings is based on logistic regression analysis in order to investigate the impact of the aforementioned factors on the competitive advantages of the start-ups.

\section{Literature Review}

Sustainability of start-ups is a measure influenced by a multitude of variables [17]. Recent data in OECD countries show that the average survival rate of start-ups three years after founding is $60 \%$, while the corresponding percentages for 5 and 7 years are $50 \%$ and $40 \%$ [4]. Differences that occur between countries are interpreted by various determinants related to the broader institutional framework of innovative entrepreneurship, thus high- 
lighting the importance of the "ecosystem" of start-ups. This ecosystem concerns all the interest groups involved, including other businesses, governments, universities, investors, independent professionals, and support organizations, without whom the survival of a start-up company is almost impossible [18]. This article examines the dimensions, including enabling factors, which constitute the start-up ecosystem, the relationships between them, as well as how they influence the competitiveness of start-ups. Nevertheless, much of the previous research mainly focused on aspects of start-uppers' behavior (such as individuals' nature, characteristics, and personality of individuals), product-related or service-related aspects, and internal business organization issues, rather than concentrating on the understanding of start-ups responding to environmental conditions that may facilitate or hinder their success [19-21]. Previous research highlights the importance of ethics and motivation regarding the performance of employees [22]. In this section, we review previous work and research: firstly, regarding the evolution of the quadruple helix model as a pillar for innovative entrepreneurship and, secondly, determining and examining contextual factors of the start-up ecosystem with a significant impact on the evolution and success of a start-up. Finally, we develop and propose a conceptual framework in order to better understand the structure of a start-up ecosystem, as well as the influence of its drivers on the start-ups' competitive advantage.

\subsection{The Triple and Quadruple Helix Model}

Innovation is not the result derived by just one institutional player, such as universities or industries, but rather is a result of the interaction between all actors in the ecosystem as a source of new organizational plans [23]. At the heart of this shift is the triple helix model, which was proposed about two decades ago [24,25]. At its core, the triple helix model claims a new institutional foundation for the development of innovation, which is no longer produced by a single institution, but instead by the triadic networking between the academic community, industry, and the government [26-28]. It is currently a global hybrid model for the promotion and innovation of research with internationalized characteristics, although regulations related to the operation of businesses, universities, and the state vary greatly from country to country [29]. At the same time, there is insufficient research evidence regarding the optimal strategy mix and the arrangements and practices required to move from static and noninvasive models to the most modern hybrid models [27].

At present, universities maintain a central role in the process of innovation by producing knowledge in a multidisciplinary process, using and commercializing it, supporting the development of new enterprises, and undertaking various business functions [30] through the term "entrepreneurial universities" [31]. These universities are actively involved in the capitalization of knowledge, playing a key role in networking between different actors that promote innovation. At the same time, outside of academia, the role of the industry is similarly upgraded within the triple helix model. Not only are universities evolving into entrepreneurial institutions, but also enterprises themselves incorporate traditional academic functions, such as the creation of R\&D departments, training and professional development of staff, as well as the diffusion of knowledge [30]. In addition, universities contribute to the exchange of know-how through the creation of spin-off businesses that undertake the transformation of research into applied services and products. Spin-offs play an important role for the process of know-how transfer and commercialization of technological innovation [32].

From the above, it appears that the high degree of overlapping of university and industry activities suggests a hybrid model, in which the simultaneous presence of competition and co-operation puts forward a new "co-competition" model, creating collaborative R\&D projects between universities and businesses, promoting the creation of entrepreneurship incubators, etc. [33].

The main relationships between the three institutional factors in the triple helix model are the following [23]: (1) technology transfer, (2) co-operation and conflict resolution, (3) collaborative leadership, (4) substitution of certain functions, and (5) networking. In 
particular, technology transfer is a key element of the triple helix, especially in areas of high innovation [34]. Universities, technology transfer offices, science parks, and start-up incubators and accelerators are just a few of the examples of intermediary entities that facilitate the capitalization of knowledge and its dissemination in the industries [35]. At the same time, knowledge transfer is also indirectly implemented through entrepreneurship education, resulting in universities contributing to economic growth and employability [36].

In addition, conflict management between the different roles of the three key institutional factors is a key component of the triple helix model. These conflicts concern both the individual tasks and functions, as well as the interpersonal relationships developed between them [23]. An example of such a collisional situation is when the business activities of universities are not in line with sovereign academic norms, as is the case with researchers who fear that they will lose their independence when involved in business [37]. Another example is the resolution of the field of copyright protection so that inventions implemented in universities are used in the public interest [38]. The role of the state in this case is extremely important, especially in terms of monitoring and controlling the links between education and industry, as well as in developing networks of co-operation and exchange of good business practices.

In this context, researchers have proposed some variations of the model in recent years in order to integrate additional variables that affect collaboration between public organizations, the academic community, and the business world. In particular, they proposed the quadruple helix model, which — in addition to the three key institutional bodies-also takes into account the role of culture and civil society and the mass media [39].

The quadruple helix model is characterized by a high degree of sensitivity in terms of the impact of the knowledge that society and democratic fermentations carried out on a global scale, while recognizing the importance of the environmental framework of society and the economy [40]. The interactions that occur in the wider social context are a basic variable of the process of innovation production and new knowledge in modern economies. In addition, particular emphasis is placed on institutional planning and change, i.e., the systematic processes of renewing and reforming the institutional framework for governing innovative entrepreneurship. This model refers to an ecosystem in which all the actors involved co-operate in a co-ordinated way [41].

\subsection{Start-Up Entrepreneurial Ecosystem Determinants}

Entrepreneurial ecosystems include the entities involved in the quadruple helix model, the action of which determines their business path and success. Especially in the case of start-up businesses that are characterized by a high degree of technological innovation and service provision at a global level, the need for interconnection with other ecosystem actors is even more important [42]. The ASPEN Institute [43] analyzes the existing entrepreneurial ecosystem frameworks and proposes the main determinants of the ecosystem that affect entrepreneurial success.

Based on the literature review regarding academic databases (Scopus, EBSCO, Elsevier, Spinger, etc.), as well as online publications, the factors affecting the sustainability of startups can be summarized to the following determinants.

\subsubsection{Education and Research}

According to a meta-analysis for the effects of entrepreneurship education, there is an important link between entrepreneurship education and business performance [44]. Education, and especially start-up business training, is an important factor contributing to the profitability of a start-up business [45]. Surveys indicate the contribution of business education to business success [46]. Start-uppers who have greater access to knowledge from the beginning are more likely to survive. Therefore, they are in a more favorable position than the others [47]. Moreover, an earlier study found that general education has a greater impact on the success of new entrepreneurship compared to past experience [48]. Similarly, Allen and Hall [49], exploring the views of 100 founder newcomers, have documented that 
those with a higher level of education are more likely to engage in innovative activities, while the ability to access venture capital is also improved. Similarly, another survey finds that young entrepreneurs have received higher education and their activity was motivated by their need to create wealth, to be autonomous, and to implement an innovative idea [50]. However, knowledge alone is not enough to create innovation [51].

\subsubsection{Human Capital}

According to Chorev, studying the success factors of Israeli start-up businesses, choosing the right human resources and their loyalty to the start-up business are highlighted as the most important factors [52]. In addition, research carried out on a sample of young entrepreneurs found that previous work experience of their founders positively affects their performance [53]. The existence of past experience enables potential entrepreneurs to recognize market opportunities and make the best use of these [54]. In this context, there is a clear distinction between first-time entrepreneurs and start-uppers with previous experience, which has a decisive impact on their success [55]. In addition, a meta-analysis describes how the skills of the start-upper and the team affect its success [42].

\subsubsection{Finance and Funding}

Financing of start-ups is a matter of particular research interest, as new innovative companies often encounter difficulties in raising funds while having limited cash flows in their early stages [56]. The problem of finding funding is one of the most important difficulties facing start-ups [57]. Moreover, it has been shown that cash flows and holdings contribute emphatically to the productivity and profitability of businesses [58]. Financing is a crucial factor not only in the early phases of operation, but it greatly affects the profit of a start-up business [59].

The impact of venture capital on innovation activities and the success of start-ups is particularly important and, in fact, of a long-term nature [60]. Venture capital has the most significant impact on the promotion of innovative entrepreneurship over any other form of funding [61]. These affect the start-ups through two key mechanisms: firstly, directly through the provision of finance and human capital and, secondly, indirectly by providing access to further financing institutes, thus taking on a mediating role [62]. In addition, the benefits of venture capital financing are multiple, as venture capital firms provide start-ups with human capital with upgraded management and management skills, experience, and expertise [63]. Another major source of funding for start-ups is angel investors, individuals who provide capital but also nonfinancial resources, such as knowledge, experience, mentoring, and networking. In the U.S., it is estimated that a significant proportion of start-ups that have raised funds from VCs have previously been funded by angel investors, while the same applies to $8 \%$ of NASDAQ-registered companies between 2001 and 2007 [64]. What differentiates angel investors from venture capitals is that the funding they provide mainly concerns the early stages of setting up and running a start-up business [65]. VCs only invest $1 \%$ in the first stage of setting up a start-up company, $18 \%$ in their early stages, and the remaining percentage is in later growth stages [66].

\subsubsection{Government}

The supportive role of the state in the broader ecosystem of entrepreneurship is of particular research interest presently, and it has been argued that the state can be involved in some areas of high-risk activities where the private sector consistently avoids participating [67]. A typical example of these government interventions is the U.S., where many business ecosystems, such as Silicon Valley, have benefited from the active role of the state [68]. In the example of Silicon Valley, governments also play an important role in the financing sector by contributing to the success of the ecosystem [69]. Of course, governments need to understand the basic mechanisms around innovation creation and diffusion, thus facilitating business activity rather than hindering it [70]. This interference is encouraged by governments in a number of ways, notably through the provision of tax 
incentives [71] on R\&D expenditure. Finally, it is worth noting that research concludes that public funding does not lead to better performance of spin-off enterprises [72].

In addition, governments can contribute by highlighting successful business models, removing bureaucratic barriers to start-ups, and mitigating the social stigma of failure [73]. Finally, the impact of the legal framework on start-ups plays an important role at various levels, such as crowdfunding, since the legal arrangements present a high degree of heterogeneity among countries; in most EU member states, the issue of shares through crowdfunding is forbidden [74].

\subsubsection{Business Support and Connectedness}

Networking of the new entrepreneur addresses all the relationships they develop with various institutions and organizations and is critical to the success of their start-up [75]. The performance of start-ups is directly influenced by the quality of their networks and their ability to exploit the resources they have access to through these relationships [76]. Startup networking capability facilitates the development of knowledge-intensive products, enabling them to globalize effectively [77].

According to recent research, the use of business networks for start-up businesses is very important [78]. In addition, support and collaboration contribute to the success of new products [79]. As fresh ideas are brought to market and developed into commercially viable projects, start-ups play an important part in the innovation process. Existing research indicates that open innovation (involving any form of external partners) is a priority for the success of start-ups [80]. In particular, the involvement of start-ups in incubators is becoming increasingly critical [81] for sustainability in its early development phases. Incubators provide supportive services and help young entrepreneurs to develop their business [82,83]. Research in Portugal [84] highlights the role of science parks and incubators in the macroeconomic growth of countries. Finally, incubators contribute to increasing the availability, awareness, accessibility, and affordability of economic, human, intellectual, or even social capital, which are identified as the key components of business success [85].

\subsubsection{Entrepreneurial Culture and Incentives of Start-Up Creation}

The study of innovative entrepreneurship is not limited to the above contextual factors that affect its success. The social context in which the start-upper lives, works, and shapes both his business culture and business motivations is crucial. A survey conducted in France and the U.S. shows that there are attitudes in France that are less positive towards entrepreneurship [32]. Entrepreneurship also relates to the background and personality of the new entrepreneur [86]. In particular, many young entrepreneurs in the U.S. do not have great expectations for the development of their companies, as they are often motivated by personal reasons related to their desire to be autonomous or to have flexible working hours [87]. Oftentimes, innovative entrepreneurship is an alternative to the uncertain future that young people face in the labor market, especially in periods of high unemployment rates [88]. The incentives to create a new business are split into incentives for opportunity and incentives for necessity [89]; the former are characterized by previous experience, as well as appropriate training and skills, which helps them to cope with the challenges [90], thus having higher success rates than the latter [91]. In contrast, necessity entrepreneurship driven by the need for occupational safety has a negative impact on the creation of new jobs and economic growth [92] and is more likely to fail [93]. In addition, there is evidence that start-ups facing funding issues have mainly necessity motivations [90].

\section{Conceptual Framework for Start-Up Entrepreneurial Ecosystems (StUpEco)}

The present study aims to highlight the contextual drivers of a start-up business that are affected by the entrepreneurial ecosystem entities involved within the quadruple helix model, focusing on their relationships and significance within the case of the Greek start-up ecosystem. There are various organizations that affect the operations of a start-up company in Greece, consisting of universities, research institutes, technology parks, start-up 
accelerators, pre- and post-incubators, co-working spaces, service providers, event organizers, advisory and mentoring organizations, governmental agencies, funding providers (loans, grants, crowdfunding portals), investor networks (business angels), venture capital companies and structures belonging to civil society (meetups, communities), and other facilitators (Table 1).

Table 1. Facilitators of a start-up ecosystem in Greece.

\begin{tabular}{|c|c|c|c|c|}
\hline \multirow{2}{*}{ Enabling Factors } & \multicolumn{4}{|c|}{ Helices of the Quadruple Helix Model } \\
\hline & University & Industry & Government & Civil Society \\
\hline Education and Research & $\begin{array}{c}\text { Universities } \\
\text { Research Institutes } \\
\text { Technology Parks }\end{array}$ & $\begin{array}{c}\text { Business mentors } \\
\text { Seminars } \\
\text { R \& D \& I departments }\end{array}$ & $\begin{array}{c}\text { National/European } \\
\text { Education/Research } \\
\text { Policy }\end{array}$ & Meetups \\
\hline Human Resources & $\begin{array}{c}\text { Students } \\
\text { Internship offices }\end{array}$ & $\begin{array}{c}\text { Recruiters } \\
\text { Business Partners }\end{array}$ & Employment agencies & $\begin{array}{l}\text { Skilled Personnel } \\
\text { Idea bearers }\end{array}$ \\
\hline Networking and Support & Pre-incubators & $\begin{array}{l}\text { Coworking spaces, } \\
\text { Incubators, } \\
\text { Accelerators }\end{array}$ & Patent offices & $\begin{array}{c}\text { Meetups and } \\
\text { Communities News }\end{array}$ \\
\hline $\begin{array}{l}\text { Governmental } \\
\text { Interventions }\end{array}$ & $\begin{array}{l}\text { Legislation Taxation } \\
\text { regarding Education } \\
\text { and Research } \\
\text { Institutes }\end{array}$ & $\begin{array}{c}\text { Legislation, Tax } \\
\text { incentives for } \\
\text { innovation business } \\
\text { activities }\end{array}$ & $\begin{array}{l}\text { National Legislation } \\
\text { and Taxation Policy }\end{array}$ & $\begin{array}{c}\text { Feedback, } \\
\text { Open government }\end{array}$ \\
\hline Funding & Innovation Contests & $\begin{array}{c}\text { Venture Capital, } \\
\text { Business Angels, Banks, } \\
\text { Contests }\end{array}$ & $\begin{array}{l}\text { Public funding } \\
\text { E.U. funding }\end{array}$ & Crowdfunding NGOs \\
\hline
\end{tabular}

As presented in the previous section, current research around innovation implies and explores innovation as the combined effect of interactions between businesses, government, and the academic community, focusing on collective social processes and networking between different stakeholders and interest groups.

Based on the above literature review, we propose the following StUpEco framework, including the facilitators for the sustainability of start-ups (Figure 1). 


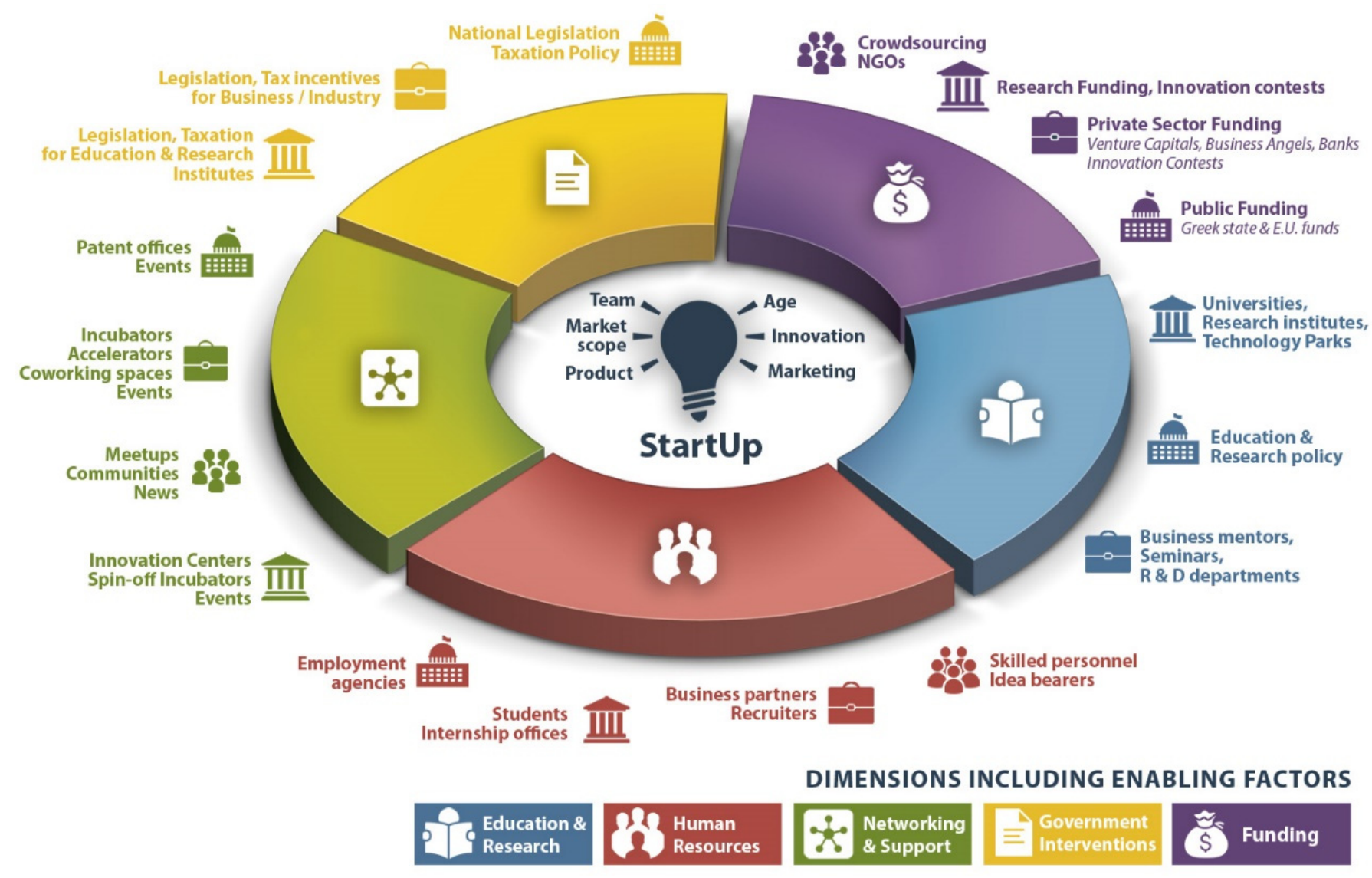

QUADRUPLE HELIX ENTITIES

Figure 1. A quadruple helix approach on enabling factors of the Greek start-up ecosystem.

\section{Theoretical Background and Survey Materials}

A theoretical background regarding valid scientific constructs has been explored in order to identify the research questions of the survey regarding the Greek start-up ecosystem.

Previous surveys highlight several factors that affect the success of a start-up business [52,94-96]. In this study, we examine the contextual factors that can be defined and influenced by the Greek start-up ecosystem. The study does not address factors such as those that focus on the internal process of the start-up business (strategy, management style, team solidarity), nor the characteristics of the product or service (level of innovation, quality, price). Furthermore, factors that are associated with consumers (customer needs, buying behavior) cannot be analyzed at the regional ecosystem level, since start-ups are addressed to an internationalized market and are therefore excluded. Taking this path, the aim of this study is to review empirical research on start-up ecosystems in order to identify factors that enable a successful implementation of start-ups.

Based on the determinants of the start-up ecosystem, the following contextual factors are extracted from previous studies (Table 2). 
Table 2. Contextual factors as identified from the literature.

Drivers for Entrepreneurial Success

Prior start-up experience; nongovernmental financial support; patent protection; R\&D alliances; financial resources; founders' experience; university partnerships

Government policies; political stability; access to talent; prior experience; mentorship; network connections; financial funding, tax/legal support; workshops/events

Core team expertise; consultants; networking in general; funding type; political situation; entrepreneurship education; availability of skilled workforce; government support; economic situation

\begin{tabular}{lc}
\hline $\begin{array}{l}\text { Entrepreneurial skills; general education; owner experience; work } \\
\text { experience; business education }\end{array}$ & {$[42]$} \\
\hline $\begin{array}{l}\text { Work experience; education low/high; motivation; third party money; } \\
\text { network; information and guidance }\end{array}$ & {$[98]$} \\
\hline $\begin{array}{l}\text { Supportive culture; worker talent; investment capital; networks; mentors; } \\
\text { policy and governance; universities; support services }\end{array}$ & {$[10]$} \\
\hline Prior entrepreneurial exposure; entrepreneurship education & {$[99]$} \\
\hline Higher education; industry experience; support & {$[100]$} \\
\hline Entrepreneurial experience & {$[101]$} \\
\hline $\begin{array}{l}\text { Government policy; entrepreneurial finance; government entrepreneurship } \\
\text { programs; entrepreneurship education; research and development transfer; }\end{array}$ & {$[102]$} \\
commercial and legal infrastructure; entry regulation; cultural and social norms & \\
\hline $\begin{array}{l}\text { Quality of education; graduation rates; entrepreneurial motivation; patents; } \\
\text { VC access; access to angels; access to grants; cost to start business; tax rates; } \\
\text { tax incentives; access to telecom; access to electricity; access to infrastructure; } \\
\text { access to legal/accounting services; support from incubators; industry } \\
\text { networks; research and innovation, financial conditions }\end{array}$ & {$[103]$} \\
\hline $\begin{array}{l}\text { Start-up skills; networking; cultural support; human capital; culture; } \\
\text { research and innovation }\end{array}$ & {$[104]$} \\
\hline Education and training; work experience; social networking & {$[105]$} \\
\hline High-qualified personnel, funding received & {$[59]$} \\
\hline
\end{tabular}

\subsection{Education and Research}

In Table 3, the factors that constitute the education and research factor are shown. These studies were derived from the literature and indicate that the education and research factor consists of entrepreneurial education, education from mentors, staff education, and research excellence and patents. Education and research is introduced in the study to examine education as a rule of the know-how and their potentials.

Table 3. Construction of the education and research factor from the literature.

\begin{tabular}{lc}
\hline & Selected Studies \\
\hline EDU1-Entrepreneurial education & {$[42,52,98-100,102,103]$} \\
EDU2-Education from mentors & {$[10,52,95]$} \\
EDU3-Staff education & {$[42,105]$} \\
EDU4-Research excellence and patents & {$[97,103]$} \\
\hline
\end{tabular}

\subsection{Human Resources}

In Table 4, the factors that constitute the human resources factor are shown. The human resources factor is a highly significant factor for start-ups and consists of the experience, staff skills, and knowledge of the market. 
Table 4. Construction of the human resources factor from the literature.

\begin{tabular}{lc}
\hline & Selected Studies \\
\hline HR1-Start-up/Work experience & {$[42,52,95,97-101,105]$} \\
HR2-Staff with necessary skills & {$[10,42,52,59,95,104]$} \\
HR3-Knowledge of the market & {$[42,52,97,105]$} \\
\hline
\end{tabular}

\subsection{Funding and Finance Opportunities}

Since the proposed model is applied in Greece, a country that has been facing a severe economic crisis since 2009, funding opportunities are exceptionally important for start-up companies in Greece and in any other country. This factor consists of access of start-up companies to funding opportunities, as well as positive macroeconomic conditions, which are necessary for growth (Table 5).

Table 5. Construction of the funding and finance factor from the literature.

\begin{tabular}{lc}
\hline & Selected Studies \\
\hline FUN1-Available funding opportunities & {$[95,97,98]$} \\
FUN2-Adequate funding received & {$[59,97,102]$} \\
FUN3-Access to private funding & {$[10,103]$} \\
FUN4-Access to public grants & {$[52,102,103]$} \\
FUN5-Positive macroeconomic conditions & {$[52,103]$} \\
\hline
\end{tabular}

\subsection{Policy and Government Interventions}

In this sub-section, policy and governmental interventions are discussed and analyzed. Government is a determinant factor regarding the smooth operation, as it can impose legislation based on which businesses work and make profit. Moreover, another major factor in the governmental construct is taxation and how "flexible" the framework is in a country proxied with surrogate measures of bureaucracy issues (Table 6).

Table 6. Construction of the government interventions factor from the literature.

\begin{tabular}{lc}
\hline & Selected Studies \\
\hline GOV1-Resolve legal and bureaucracy issues & {$[10,95,102]$} \\
GOV2-Stable political environment & {$[52,95]$} \\
GOV3-Accelerate start procedures & {$[10,95,102,103]$} \\
GOV4-Information/Organization of events & {$[95,98]$} \\
GOV5-Favorable taxation & {$[10,52,95,103]$} \\
\hline
\end{tabular}

\subsection{Networking and Infrastructure Support}

Finally, the networking and infrastructure support construct is formulated. This construct is quite significant, especially for start-ups. Since start-ups are newborn businesses with a unique type of operations, networking with various organizations, such as academia, research institutes, and primarily incubators, is vital (Table 7).

Table 7. Construction of the networking and infrastructure support factor from the literature.

\begin{tabular}{lc}
\hline & Selected Studies \\
\hline SUP1-Networking with Research Institutes & {$[97,102-104]$} \\
SUP2-Networking with Academia & {$[10,97]$} \\
SUP3-Networking with Incubators & {$[10,98,103]$} \\
SUP4-Networking with Industry & {$[98,102,103]$} \\
SUP5-Access to infrastructure and service providers & {$[102,103]$} \\
\hline
\end{tabular}




\subsection{Competitive Advantage}

The competitive advantage of a business is a term that has been researched over the past decades. It is recognized as the power that a business has over its competitors and can be gained by offering a product or service with increased value [105]. Companies can achieve a competitive advantage over their competitors by incorporating in terms of cost improvement and differentiation [106]. The survival of new technology-based start-ups benefits from the synergetic effect of combining resources [107]. Three approaches have been recognized as applicable to all businesses: cost leadership strategy, differential strategy, and focus strategy. In that perspective, several resources have been linked to competitive advantage, such as:

- COM1: Implementation of innovation [106].

- COM2: Use of high technology [107,108].

- COM3: Interconnections and knowledge transfer between actors of the ecosystem [109,110].

- COM4: Coaching and support by business mentors [111,112].

- COM5: Organizational culture including the effective cooperation within the company $[113,114]$.

- COM6: Previous business and start-up experience of the team $[115,116]$.

- COM7: Education and technical skills of the founders [117].

\subsection{Research Survey}

A survey focusing on the Greek start-up entrepreneurial ecosystem was conducted aiming to research, study, and evaluate the enabling factors considered as critical to startups' success and sustainability. The proposed conceptual framework (StUpEco) has been tested according to the perceptions of Greek start-uppers with a questionnaire delivered among 302 Greek start-up participants. The first part highlights both the start-up and startupper's profiles: number of employees, number of founders, sector, start-up incentives and motivation, funding sources used, and co-operation with other entities. The second part refers to personal views about the importance of the actors in the Greek start-up ecosystem and examines their views on the factors that determine their competitive advantage. The questionnaire is available as an appendix (Appendix A). Firstly, 482 established start-up companies have been identified through personal networking during live and online events of OpenCoffee Thessaloniki, OpenCoffee Athens, and StartupWeekend Thessaloniki, socialmedia-related groups, and start-up presentation websites, such as startupgreece.gov.gr (accessed on 21 June 2020). It is worth mentioning that only one co-founder from each start-up participated in the questionnaire and the start-ups selected had already started their business activities in a legal business form. The response rate is $62.6 \%$. The sample is deemed to be satisfactory based on the overall size of established start-up companies within the research timeframe.

\section{Findings}

\subsection{Descriptive Statistics Results}

A selection of basic statistics regarding the functionality of start-ups in our sample is presented in this section of the study. With regards to the number of founders, $45.5 \%$ of start-ups consist of two founders, $24.8 \%$ of thre founders, $18.2 \%$ of one founder, $9.1 \%$ of four founders, $1.7 \%$ of five founders, and $0.8 \%$ of more than five founders (Figure 2). 


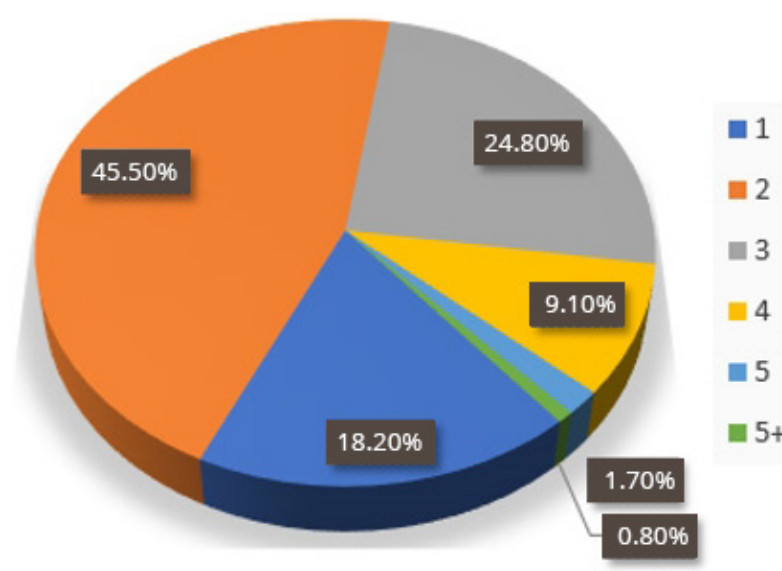

Figure 2. Frequency pie chart of number of founders.

Another finding regarding the functionality of a start-up is the number of employees. Most start-ups are small businesses with less than five employees ( $81 \%)$. Start-ups with a labor force between 6 and 10 employees constitute $9.9 \%$, while only $2.5 \%$ of the population employs more than 30 employees (Figure 3).

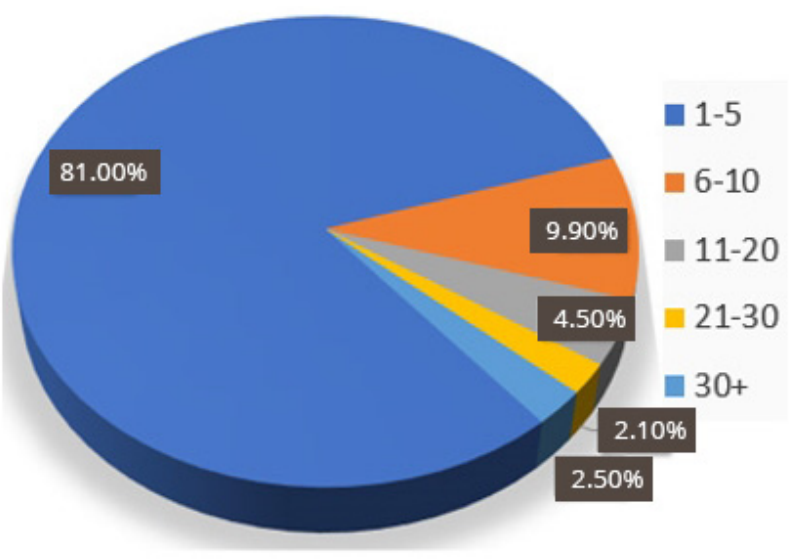

Figure 3. Frequency pie chart of number of employees.

The profile of start-ups examined in this paper covers a wide range of sectors. More specifically, a large percentage of start-ups $(61.2 \%)$ work mainly in the field of new technologies. The rest of the categories account for significantly lower percentages, with $9.9 \%$ of start-ups working in tourism, $5.8 \%$ in education, $4.1 \%$ in trade, $3.3 \%$ in health services, $2.5 \%$ in transportation and agriculture, and $1.7 \%$ in food and beverages and construction, whereas $7.4 \%$ work in other sectors.

With regards to the sources of funding received, the clear majority of start-uppers have invested their personal funds in order to support their start-up. Findings indicate that $23 \%$ of them gained funds from friends and family, while $8 \%$ received support from state and EU subsidies; $19 \%$ were supported by private institutions: $7 \%$ by incubators, $5 \%$ by business angels and venture capitals, $4 \%$ by banks, and $3 \%$ through innovation contest; while only $3 \%$ have used crowdfunding to develop their idea. It is well mentioned that only $1 \%$ have been supported by education and research institutes (Figure 4 ). 


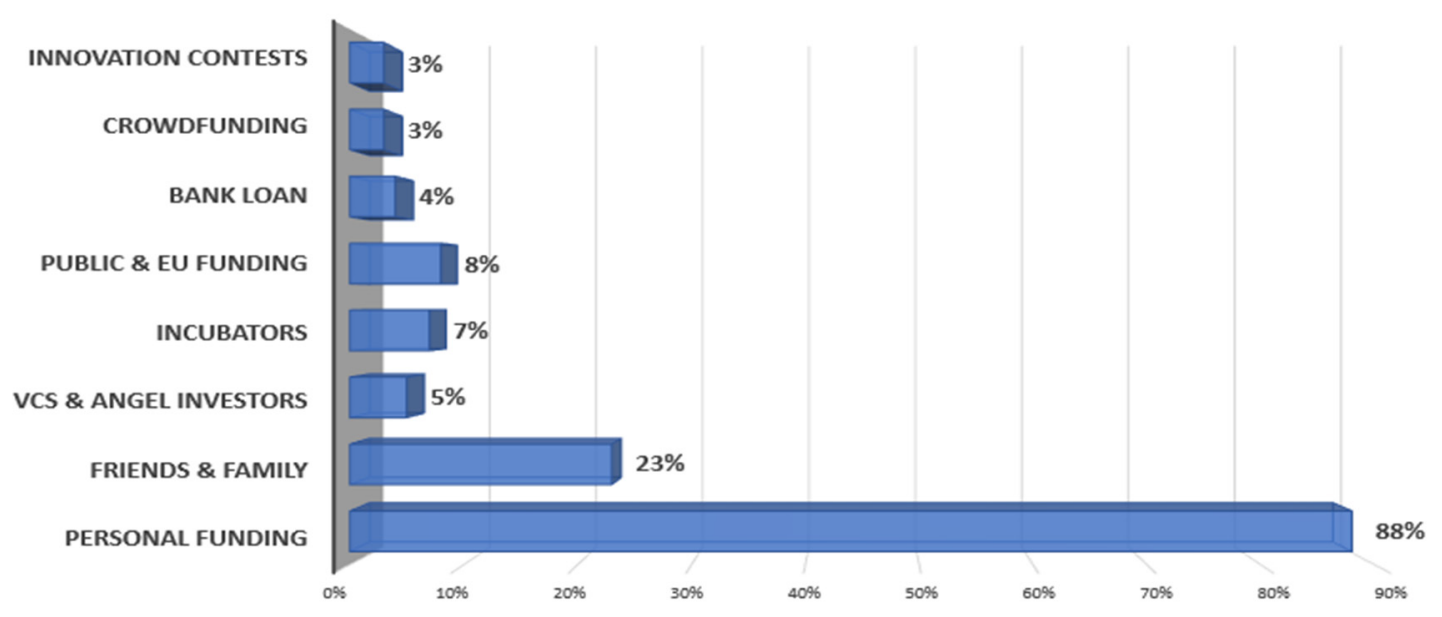

Figure 4. Funding sources of Greek start-ups.

Finally, the descriptive statistics are reported in conclusion with the analysis of the startup connections regarding enabling factors of four main dimensions: funding, networking, human capital, and education and research. Based on the results, as can be seen in Figure 5, the highest percentages of start-ups have been primarily based on civil society structures $(52 \%)$ and private institutes $(31 \%)$, with regards to their networking and connectedness. As for the education and research sector, these have mostly been influenced by universities $(44 \%)$, while they mostly co-operated with structures belonging to the industry helix (52\%) regarding the human capital sector. Last but not least, since funding is one of the primary "fuels" for a start-up, the vast majority of them (46\%) did not connect with any of the four helices in one way or another (Figure 5).

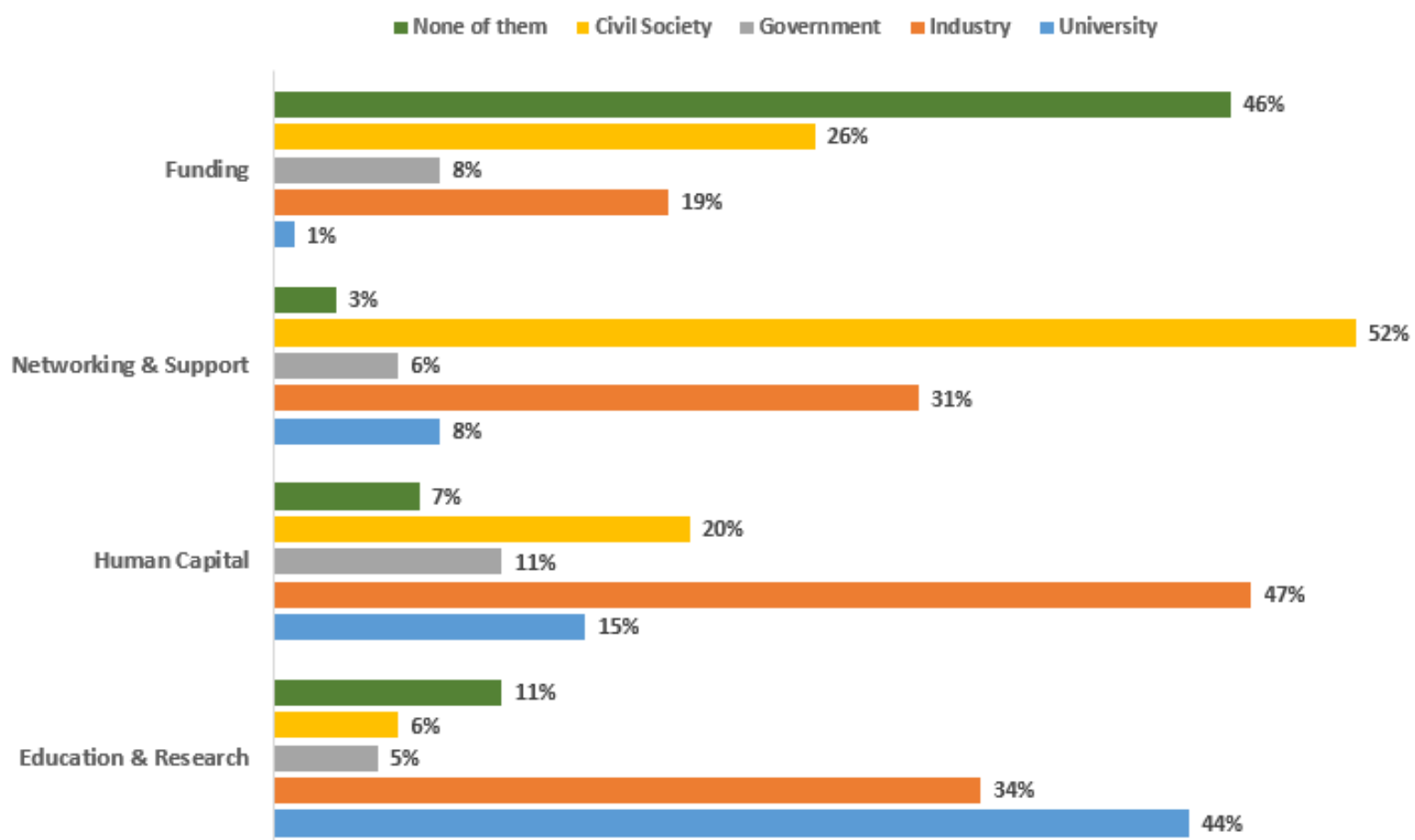

Figure 5. Stacked barplot describing start-up connections with ecosystem entities.

Regarding the incentives for start-up creation, $61.6 \%$ were created because there was a market opportunity and $38.4 \%$ were created due to need.

In order to draw conclusions by analyzing the current state of start-ups in Greece, crosstabulations are formed. In Figure 6, variable COM1 (implementation of innovation) 
is analyzed in comparison to the incentives of business creation because of necessity and opportunity (namely, need or opportunity). The results show that, with respect to need motivation, respondents replied that innovation is neutral as a factor to competitive advantage; however, the opportunity motivation factor seems to concentrate a large percentage of responses. Based on the latter finding, it can be seen that, from the respondents of opportunity motivation factor, innovation is of high importance to the formation of a new start-up (Figure 6).

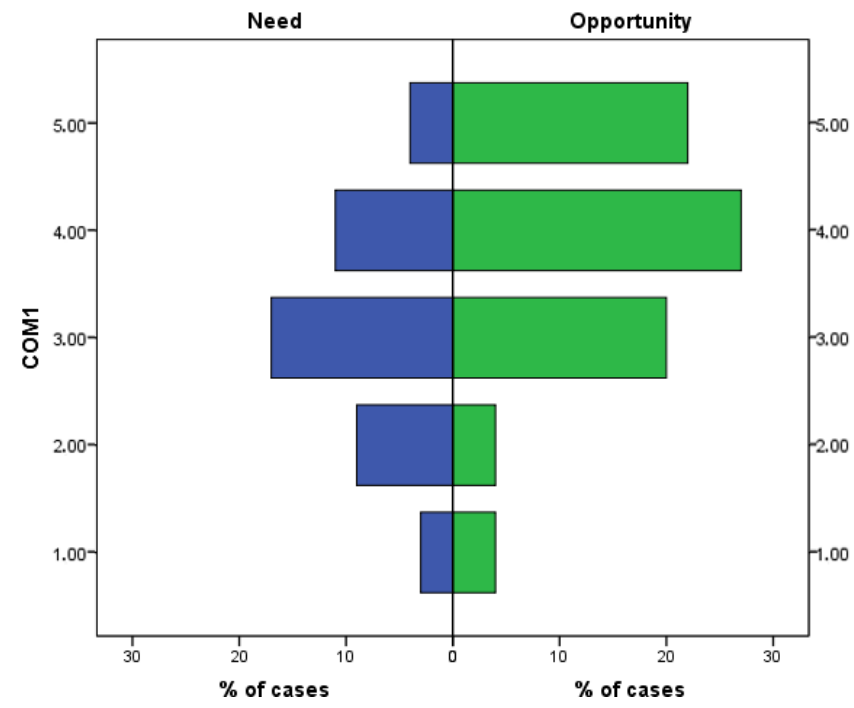

Figure 6. Barplot of COM1 (implementation of innovation) split per need and opportunity.

In Figure 7, it can be seen that, regarding the cutting-edge technology (COM2), the opportunity motivation factor accumulates the most responses, based on which start-up founders evaluate the cutting-edge technology factor for competitive advantage (Figure 7).

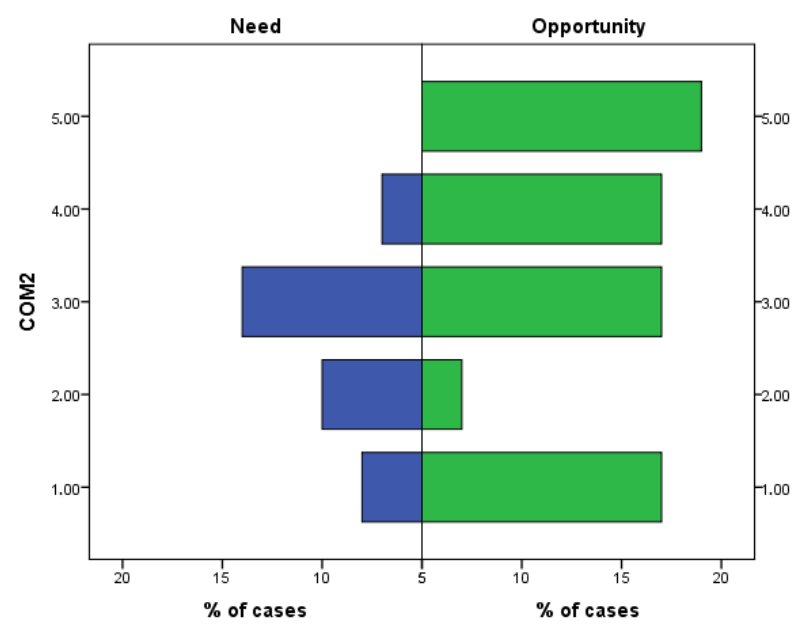

Figure 7. Barplot of COM2 (use of cutting-edge technology) split per need and opportunity.

The same conclusion, as with Figure 7, can be drawn from Figure 8. The majority of the responses of the factor associated with co-operation with other organizations (COM3) demonstrate more responses for the opportunity motivation factor, while co-operation is considered as very important (Figure 8). In Figure 9, variable COM6 (previous start-up experience of the founders) is analyzed in comparison to the driving force for the formation of a new start-up (namely, need or opportunity). The results show that, with respect to need motivation, respondents replied that previous start-up experience is not considered as a significant factor to competitive advantage; however, the opportunity motivation factor 
seems to accumulate a large percentage of responses. Based on the latter finding, it can be observed that, based on the respondents of the opportunity motivation factor, previous business experience is of high importance to the formation of a new start-up (Figure 9).

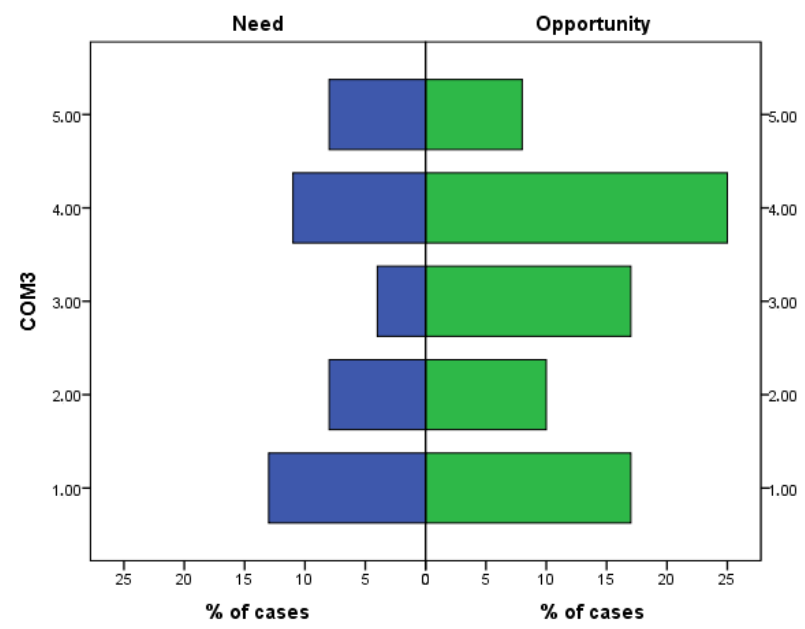

Figure 8. Barplot of COM3 (efficient co-operation with other actors of the ecosystem) split per need and opportunity.

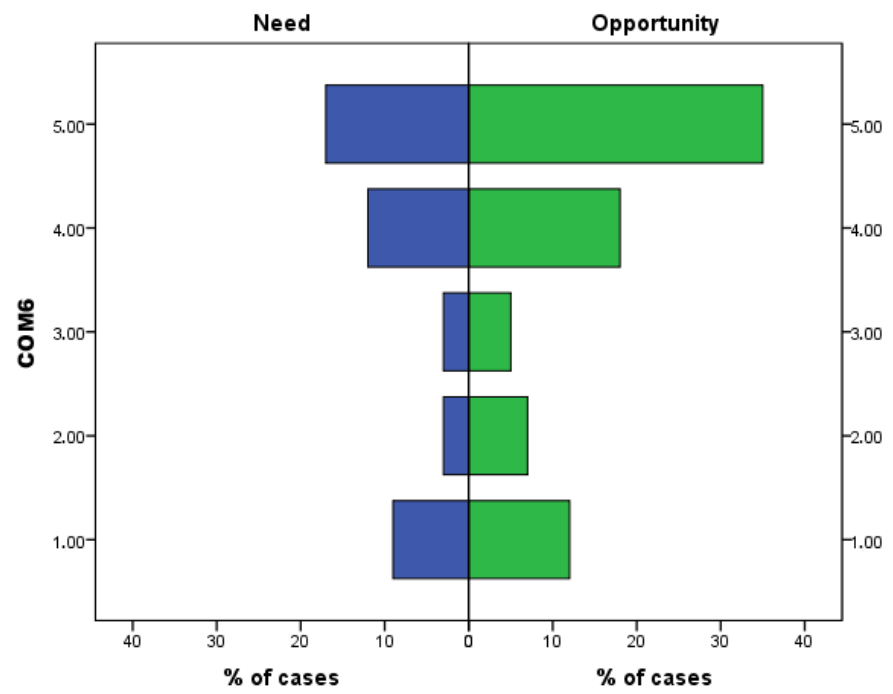

Figure 9. Barplot of COM6 (previous start-up experience of the founders) split per need and opportunity.

In Figure 10, it can be observed that, regarding the founders' technical skills and knowledge (COM7), the opportunity motivation factor accumulates the most responses, based on which start-up founders evaluate their skills as a factor for competitive advantage (Figure 10). 


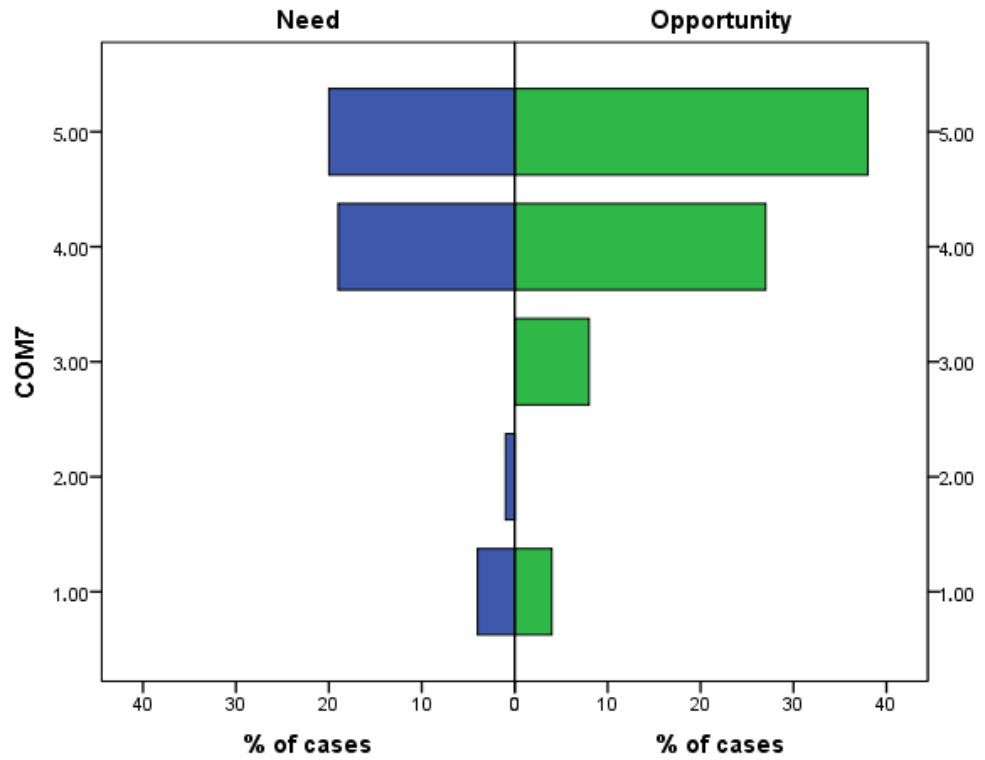

Figure 10. Barplot of COM7 (founders' technical skills and knowledge) split per need and opportunity.

\subsection{Fitness of the Structures}

To evaluate the extent to which each of the structures contribute, namely, education and research, human resources, funding and finance opportunities, business support and connectedness, and policy and government interventions, the following assumptions have been formulated. An introductory analysis is being performed for the items that formulate each "latent" variable, namely, education (EDU), funding (FUN), human resources (HR), support (SUP), and government (GOV). To evaluate the fitness of the proposed structures, Cronbach's alpha $(\alpha)$ measure is calculated. Assuming that a "latent" variable consists of $K$ components, then this "latent" variable $(Y)$ is expressed as the sum of the values of the variables that formulate the factor $\left(X_{i}\right)$. Cronbach's alpha measure is calculated as follows and receives values in the range of 0 and 1 :

$$
a=\frac{K}{K-1} \cdot \frac{\sum_{i=1}^{K} \sigma_{X_{i}}^{2}}{\sigma_{Y}^{2}}
$$

Cronbach's Alpha Results

The second part of the analysis reflects the examination of the variables that create each latent variable. As discussed above, the fitness of the factors is calculated with Cronbach's alpha $(\alpha)$. From the next table, it can be seen that all the factors adequately formulate each latent variable since $\alpha \geq 0.7$ (Table 8 ).

Table 8. Cronbach's alpha values for each latent variable.

\begin{tabular}{ccc}
\hline Latent Variable & Factors & Cronbach's Alpha \\
\hline HR & HR1-HR4 & 0.843 \\
FUN & FUN1-FUN5 & 0.847 \\
SUP & SUP1-SUP3 & 0.788 \\
EDU & EDU1-EDU3 & 0.728 \\
GOV & GOV1-GOV5 & 0.780 \\
\hline
\end{tabular}

\subsection{Analysis of Each Structure on Competitive Advantage}

The aim of the present analysis is the investigation of "latent" variables to the competitive advantage, proxied by questions regarding implementation of innovation (COM1), use of cutting-edge technology (COM2), efficient co-operation with other actors of the ecosystem (COM3), business coaching and mentoring (COM4), outstanding co-operation 
between the team members (COM5), previous start-up experience of the founders (COM6), and technical skills and knowledge of founders (COM7). In order to perform this analysis, logistic regression is applied after the data have been split into two major categories for each variable (COM1-COM7). Logistic regression is used to calculate the odds ratio when there are several explanatory variables. The influence of each variable on the odds ratio of the observed event of interest is the end outcome. The key benefit is that it eliminates confusing effects by examining the relationship between all variables [118]. Since the aforementioned variables are given a Likert scale (1-not important, 5 -very important), a recalculation of each variable is performed on the following basis: 0 (no or very little importance, values: 1 , 2 , and 3 ) and 1 (important, very important, values: 4 and 5). The mathematical formulation of logistic regression is expressed as follows:

$$
\ln \left(\frac{p(Y=1)}{1-p(Y=1)}\right)=a+b x^{T}+e
$$

In the mathematical formulation described above, $p(Y=1)$ is the percentage of the first category $(1$, mediocre to very much important), while $p(Y=0)=1-p(Y=1)$ is the percentage of the second category ( 1 , little or no importance at all). This type of analysis is suitable when the type of response is binary and the independent variables can be a mix of continuous and categorical variables of two levels. The matrix $x$ includes the independent variables and $e$ is the vector of error terms, which is supposed to be normally, independently, and identically distributed. Lastly, coefficients $a$ and $b$ present the intercept and slope and are estimated using maximum likelihood (ML).

Logistic Regression Analysis

As can be seen from Table 8, each of the studies formulates a larger unobserved structure, the latent variable. For example, variables HR1-HR4 formulate the latent variable HR. The aim of the modeling is to evaluate the impact of each variable on the dependent variables (competitive advantage variables COM1-COM7). However, the aim of the analysis focuses on the investigation of interaction of each larger structure (HR, FUN, etc.) on each competitive advantage factor. Each logistic regression is shown in Tables 9-14, where only the statistically significant coefficients are kept.

Table 9. Logistic regression results for COM1 (implementation of innovation) independent variable.

\begin{tabular}{ccc}
\hline & $\beta$ & $p$-Value \\
\hline HR & 0.006 & 0.608 \\
SUP & 0.055 & 0.017 \\
GOV & 0.128 & 0.00 \\
Constant & -1.609 & 0.00 \\
\hline
\end{tabular}

Table 10. Logistic regression results for COM2 (use of cutting-edge technology) independent variable.

\begin{tabular}{ccc}
\hline & $\beta$ & $p$-Value \\
\hline HR & 0.007 & 0.583 \\
FUN & 0.026 & 0.081 \\
GOV & 0.084 & 0.00 \\
Constant & -1.713 & 0.00 \\
\hline
\end{tabular}


Table 11. Logistic regression results for COM3 (co-operation with other actors of the ecosystem) independent variable.

\begin{tabular}{ccc}
\hline & $\boldsymbol{\beta}$ & $p$-Value \\
\hline FUN & 0.008 & 0.589 \\
GOV & 0.091 & 0.00 \\
SUP & 0.162 & 0.00 \\
Constant & -2.993 & 0.00 \\
\hline
\end{tabular}

Table 12. Logistic regression results for COM4 (business coaching and mentoring) independent variable.

\begin{tabular}{ccc}
\hline & $\boldsymbol{\beta}$ & $\boldsymbol{p}$-Value \\
\hline FUN & 0.043 & 0.07 \\
GOV & 0.159 & 0.00 \\
SUP & 0.255 & 0.00 \\
EDU & 0.099 & 0.03 \\
Constant & -5.070 & 0.00 \\
\hline
\end{tabular}

Table 13. Logistic regression results for COM5 (co-operation between the team) independent variable.

\begin{tabular}{ccc}
\hline & $\boldsymbol{\beta}$ & $\boldsymbol{p}$-Value \\
\hline FUN & 0.090 & 0.00 \\
GOV & 0.053 & 0.007 \\
EDU & 0.079 & 0.00 \\
SUP & 0.016 & 0.554 \\
Constant & -3.228 & 0.00 \\
\hline
\end{tabular}

Table 14. Logistic regression results for COM6 (previous start-up experience of the founders) independent variable.

\begin{tabular}{ccc}
\hline & $\beta$ & $p$-Value \\
\hline FUN & 0.093 & 0.00 \\
EDU & 0.155 & 0.00 \\
SUP & 0.035 & 0.141 \\
HR & 0.027 & 0.00 \\
Constant & -3.347 & 0.00 \\
\hline
\end{tabular}

Based on Table 9, it can be seen that latent factor HR is not statistically significant; however, it positively affects the probability that competitive advantage related to innovation (COM1) will be considered an important factor $(\beta=0.006, p>0.05)$. Nevertheless, support ( $\beta=0.055, p=0.017)$ and government $(\beta=0.128, p<0.001)$ latent variables positively affect the competitive advantage factor and are statistically significant.

Based on Table 10, it can be seen that latent factor HR is not statistically significant; however, it positively affects the probability that competitive advantage related to cuttingedge technology (COM2) will be considered an important factor $(\beta=0.007, p>0.05)$. As expected, one of the latent variables that affect this competitive advantage factor is funding (FUN) $(\beta=0.026, p=0.081)$, while government latent variable (GOV) seems to be a positive determinant of highly important competitive advantage $(\beta=0.084, p<0.001)$.

According to Table 11, it can be observed that latent factor FUN is not statistically significant $(\beta=0.008, p>0.05)$; however, it positively affects the probability that competitive advantage related to co-operation with other organizations (COM3) will be considered an important factor. The results indicate that facilitation from governmental operations $(\beta=0.091, p<0.001)$ and support $(\beta=0.162, p<0.001)$ improves co-operation of the start-up with other organizations. 
The results from the logistic regression (Table 12) of the latent variables on mentoring (COM4) indicate that the factors that play an important role are related to funding, government, support, and education.

Based on Table 13, it is indicated that funding, government, and education factors positively affect the co-operation between founders (COM5). The support factor, even positively related, is not statistically significant $(\beta=0.016, p>0.05)$. On the other hand, latent variables of funding $(\beta=0.053, p<0.001)$, government $(\beta=0.090, p<0.01)$, and education $(\beta=0.016, p<0.001)$ are positively associated with increased importance of co-operation between founders.

Based on Table 14, it is indicated that funding, education, and human resources factors positively affect the COM6. The support factor, even positively related, is not statistically significant $(\beta=0.035, p>0.05)$. On the other hand, latent variables of funding $(\beta=0.093$, $p<0.001)$, education $(\beta=0.155, p<0.01)$, and human resources $(\beta=0.027, p<0.001)$ are positively associated with COM6.

The last competitive advantage COM7 (founders' technical skills and knowledge) did not seem to be statistically significant and has not been presented in the analysis.

\section{Discussion}

The sustainability of start-ups is a measure that is affected by many variables associated with the entrepreneur's motivation itself, as well as with the broader conditions of the entrepreneurial ecosystem that includes the entities involved in the quadruple helix model: academia, business, government, society. The actions and interconnections of these actors determine the path and sustainability of start-up companies.

Co-operation for innovation offers a fast and impactful approach to solve specific business challenges and enter new markets [119]. Start-up collaboration tends to provide opportunities for financial returns, inspiration, and insights resulting from the exchange of knowledge. There is a clear link between innovation and entrepreneurship, and open innovation dynamics tend to optimize this association to create sustainable enterprises. Start-ups may greatly profit from open innovation if they use it to overcome their disadvantages of newness and small size [120]. When they collaborate with larger firms, start-ups need to take on challenges and leverage the skills and assets of the former. Previous research among Norwegian tech companies established that collaborating with external and internal stakeholders can help overcome deficiencies in particular areas [121]. Open innovation management mandates the combination of external and internal sources of knowledge [122].

In this study, we conduct an extensive literature analysis, first on the emergence of the quadruple helix model as a pillar for start-up entrepreneurship, and then on identifying and assessing contextual aspects in the start-up entrepreneurial ecosystem. We present the conceptual framework Start-Up Entrepreneurial Ecosystem (StUpEco), which is tested according to the perspectives of Greek start-ups through an empirical survey. The competitive advantage variables are regressed against the quadruple helix components, identifying the essential components. According to this study, the vast majority of Greek start-up companies employ up to five individuals, including the founders, and they have their tax location set in Greece. As for their motivation, Greek start-uppers are driven by opportunity, since the majority of them have started their business because there was an opportunity in the market and they had an innovative idea (61.6\%), while only $38.4 \%$ started their business due to need. In terms of funding, the overwhelming majority used personal savings to convert their idea into a business; only $5 \%$ of the start-uppers have received financial support by VCs and angel investors and $8 \%$ received financial support by public funding. Finally, only $3 \%$ used crowdfunding as a funding option.

Furthermore, with regards to the interaction of start-uppers with the ecosystem in terms of education and research activities, they have been mostly influenced by universities (44\%), while, for the human capital sector, they mostly co-operated with structures belonging to the industry helix (52\%). In terms of the funding aspect, the vast majority of 
start-uppers (46\%) did not connect with any of the four helices, one way or another; they also relied on civil society structures (52\%) and private institutes (31\%) for their networking and connectedness.

Looking at the statistical analysis and investigating the motivation of the start-uppers, it is derived that the competitive advantage factors COM1 (implementation of innovation), COM2 (use of cutting-edge technology), COM3 (efficient co-operation with other actors of the ecosystem), and COM7 (founders' technical skills and knowledge) appear to have a greater impact on start-up businesses that were created because of opportunity. Along with these results, the findings in the bibliography were taken into account, according to which necessity entrepreneurship has a negative impact on the creation of new jobs and economic growth [92]; while opportunity entrepreneurship is characterized by previous experience and appropriate training and skills [90], the importance of enhancing these factors by the ecosystem entities is confirmed.

Moreover, by examining the factors through the proposed StUpEco framework, results indicate that support and government-related variables positively affect the competitive advantage factor of innovation (COM1). The government variable also seems to be a positive determinant for use of high technology (COM2). In addition to this, facilitation from governmental operations and support improve the co-operation and connectedness of the start-up with other organizations (COM3). In terms of mentoring and business coaching (COM4), the analysis highlights that the factors that play an important role are related to funding, government, support, and education. The variables of funding, government, and education are also positively associated with increased importance of co-operation between founders (COM5). Finally, variables of funding, education, and human resources are positively associated with COM6 (previous start-up experience).

\section{Conclusions}

Start-ups have become one of the key factors for the country's growth, as the number of start-ups have significantly increased over the past years, while contributing to regional development by encouraging innovation, accelerating institutional and structural changes, enhancing productivity, and introducing new products and services on the market. Nowadays, promoting and encouraging start-up entrepreneurship is even more important, considering the impact of the recent economic crisis.

Overall, it has been highlighted that start-ups contribute to employment rate as new jobs are created. Moreover, the analysis highlighted the disproportionate contribution of start-ups to employment in comparison to established companies. The research conducted on the characteristics and structural factors that compose the landscape of start-up entrepreneurship in Greece found that it is based primarily on innovative ideas and effective co-operation between the founding members and the most critical institutional bodies. However, the lack of funding and the high dependence of start-ups on personal capital jeopardize their success and viability. At the same time, their level of co-operation with other institutions is considered unsatisfactory, with the private sector dominating and research institutes playing a limited role.

The suggested StUpEco framework emphasizes the start-up business' contextual drivers, influenced by the entrepreneurial ecosystem entities included in the quadruple helix model. We propose the StUpEco framework, a hybrid model in which each of the four helices and their entities contributes to each dimension of variables that activate the success of a start-up by merging the four helices of the quadruple helix model with the enabling elements of a start-up business. In conclusion, this research explores the start-ups' ecosystem; in order to evaluate the ecosystem, a framework for start-ups is formulated. Using statistical analysis based on data from Greek start-ups, several conclusions were drawn. Initially, the factors based on which a start-up is formulated in Greece are divided into two categories, opportunity and need. As the analysis indicates, the majority of start-up companies have started their operations based on opportunity rather than necessity. 
Based on the findings of the framework, the support from other organizations and issues regarding governmental authorities (e.g., less bureaucracy) positively affect the innovation of a start-up. According to our results, the most significant issues affecting the successful development of start-ups are government issues, such as tax incentives and acceleration of starting procedures, availability of funding opportunities, connectivity of stakeholders, entrepreneurship education, previous start-up experience, incubator support, and mentoring.

The first limitation concerns the limited geographical coverage, since the study was conducted among Greek start-uppers. The second limitation is relative to the small number of respondents because the start-up ecosystem in Greece is in its early development stages. The findings cannot, therefore, be generalized and attributed to the whole world. Although this paper has specific limitations, it provides avenues for future researchers. Larger research could be conducted for European start-ups and the bigger sample could enhance data generalization. Furthermore, with regards to future research, it would be very useful to further add to this study of the proposed Start-Up Entrepreneurial Ecosystem Framework (StUpEco) by conducting measurements of the factors of the Greek start-up ecosystem, with reference to reliable opinions of Greek start-up scene experts through application of the Delphi method.

In conclusion, the present research evidently highlights the need for interconnection, as well as better communication, between the parts of the entrepreneurial ecosystem. The development of intermediaries is considered critical to the success of start-up businesses in order to bring the entities of the start-up ecosystem together. While open innovation produces opportunities for businesses to survive, only entrepreneurial awareness and visualization can transform the opportunities. It calls for new management approaches and extensive abilities in technology incorporation, and start-ups should be ready to adjust. In this light, it is clear that the institutional strengthening of the start-up ecosystem is a vital variable for the development and promotion of start-ups in Greece, upgrading the framework of co-operation between individual stakeholders, including universities, public sector companies, research institutes, and scientific bodies.

Author Contributions: Conceptualization, C.Z. and M.V.; methodology, C.Z. and K.P.; validation, K.P. and M.V.; formal analysis, C.Z.; investigation, C.Z.; resources, C.Z.; data curation, K.P.; writingoriginal draft preparation, C.Z. and K.P.; writing-review and editing, C.Z., K.P. and M.V.; visualization, C.Z.; supervision, M.V.; project administration, M.V. All authors have read and agreed to the published version of the manuscript.

Funding: This research received no external funding.

Institutional Review Board Statement: Not applicable.

Informed Consent Statement: Not applicable.

Data Availability Statement: Not applicable.

Conflicts of Interest: The authors declare no conflict of interest.

\section{Appendix A}

\section{"Start-ups in Greece"}

The purpose of the questionnaire is to investigate issues related to start-ups, (operation, development, ways of financing, interaction with the start-up ecosystem, etc.) that are based or originated from Greece.

\section{Start-up \& Start-uppers' Profile}

1. Name of Start-up:

2. What is the number of founders: 
1

2

3

4

5

$>5$

Number of founders

3. What is the number of employees:

\begin{tabular}{llllll}
\hline & $0-5$ & $6-10$ & $11-20$ & $21-30$ & $>30$ \\
\hline Number of employees & & & & & \\
\hline
\end{tabular}

4. What is the legal form of the business:

- Individual business

- $\quad$ Normal business (O.E.)

- Corporate business (E.E)

- $\quad$ SA (A.E.)

- $\quad$ Limited liability company (E.P.E.)

- $\quad$ Private Capital Company (I.K.E.)

5. The company is headquartered in:

- Greece

- USA

- England

- Cyprus

- Bulgaria

- Other

6. What is the most important reason for choosing the country of the tax headquarters:

- Place of residence

- Less competition

- Low taxation

- Less bureaucracy

- Better legal framework

- Area with more customers

- Personal reasons

- You have acquaintances who are potential partners or supporters

- Other

7. In what industry is your business classified?

- $\quad$ ICT

- Education

- Health

- Tourism

- Constructions

- Logistics

- Environment

- Agriculture

- Retail

- Other

8. What is your operating time?

- $<1$ year

- $1-2$ years

- $>2$ years

9. What is the most important motivation for creating your Start-up?

- Necessity

o Unemployment 
o Low earnings in current job

o Need for professional independence

- Opportunity

o $\quad$ Existence of a very good idea that fills a gap in the market

12. What was the main source for conceiving your start-up business idea?

- Educational activity (special course, seminars, etc.)

- Discussion with third parties

- Family environment

- An idea that has been implemented in another country

- Self-created idea

- In collaboration with University Institutions

- In collaboration with Research Bodies

- In collaboration with other companies

- In collaboration with Public Bodies

- Other

14. What financing model have you used for your start-up business? (more than one answer)

- Personal savings/funds

- Family/relatives/friends

- Crowdsourcing platforms

- $\quad$ State/EU subsidy

- $\quad$ Angel Investors \& Venture Capitals

- Loan from a Bank

- Incubators

- Innovation competition

15. Which of the following actors did you work with mainly in the individual fields?

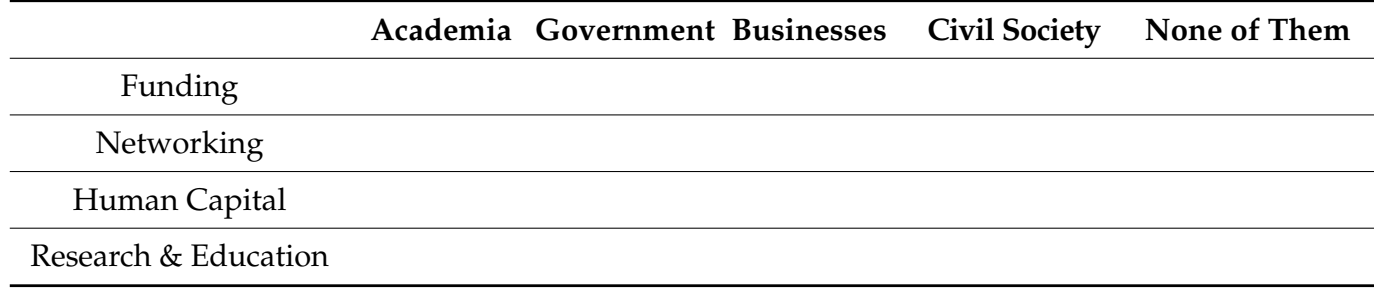

16. Which of the following difficulties did you face when starting your business? (more than one answer)

- Dealing with legal/bureaucratic/procedural issues

- $\quad$ Lack of funding

- $\quad$ Finding partners

- $\quad$ Finding staff

- $\quad$ Finding a suitable operating space

- $\quad$ Finding and using appropriate technology

- Target market approach

- Other

17. Education level of the founders (main):

- Bachelor

- Master

- Doctorate

18. Education level of the employees (main):

- Bachelor

- Master

- Doctorate 
19. Note the degree to which your start-up business has a competitive advantage

\begin{tabular}{|c|c|c|c|c|c|}
\hline & $\begin{array}{l}\text { Strongly } \\
\text { Disagree }\end{array}$ & Disagree & $\begin{array}{l}\text { Neither Agree } \\
\text { nor Disagree }\end{array}$ & Agree & $\begin{array}{l}\text { Strongly } \\
\text { Agree }\end{array}$ \\
\hline \multicolumn{6}{|l|}{$\begin{array}{l}\text { Implementation of } \\
\text { innovation COM1 }\end{array}$} \\
\hline \multicolumn{6}{|l|}{ Use of high technology COM2 } \\
\hline \multicolumn{6}{|l|}{$\begin{array}{l}\text { Interconnections and } \\
\text { knowledge transfer between } \\
\text { ecosystem actors COM3 }\end{array}$} \\
\hline \multicolumn{6}{|l|}{$\begin{array}{l}\text { Coaching and support by } \\
\text { business mentors COM } 4\end{array}$} \\
\hline \multicolumn{6}{|l|}{$\begin{array}{l}\text { Organizational } \\
\text { culture-effective } \\
\text { cooperation COM5 }\end{array}$} \\
\hline \multicolumn{6}{|l|}{$\begin{array}{l}\text { Previous business and } \\
\text { start-up experience COM6 }\end{array}$} \\
\hline $\begin{array}{l}\text { Education and technical } \\
\text { skills of the founders COM7 }\end{array}$ & & & & & \\
\hline
\end{tabular}

II. Personal Views about the Importance of the Actors in the Greek Start-up Ecosystem

20. The following factors related to EDUCATION \& RESEARCH contribute positively to the development of a startup

\begin{tabular}{|c|c|c|c|c|c|}
\hline & $\begin{array}{l}\text { Strongly } \\
\text { Disagree }\end{array}$ & Disagree & $\begin{array}{c}\text { Neither Agree } \\
\text { nor Disagree }\end{array}$ & Agree & $\begin{array}{l}\text { Strongly } \\
\text { Agree }\end{array}$ \\
\hline \multicolumn{6}{|l|}{ Entrepreneurial education EDU1 } \\
\hline \multicolumn{6}{|l|}{ Education from mentors EDU2 } \\
\hline \multicolumn{6}{|l|}{ Staff education EDU3 } \\
\hline $\begin{array}{c}\text { Research excellence \& } \\
\text { Patents EDU4 }\end{array}$ & & & & & \\
\hline
\end{tabular}

21. The following factors related to HUMAN RESOURCES contribute positively to the development of a startup

\begin{tabular}{|c|c|c|c|c|c|}
\hline & $\begin{array}{l}\text { Strongly } \\
\text { Disagree }\end{array}$ & Disagree & $\begin{array}{l}\text { Neither Agree } \\
\text { nor Disagree }\end{array}$ & Agree & $\begin{array}{l}\text { Strongly } \\
\text { Agree }\end{array}$ \\
\hline \multicolumn{6}{|l|}{ Start-up/Work experience HR1 } \\
\hline \multicolumn{6}{|l|}{ Staff with necessary skills HR2 } \\
\hline \multicolumn{6}{|l|}{ Knowledge of the market HR3 } \\
\hline \multicolumn{6}{|c|}{$\begin{array}{l}\text { 22. The following factors related to FUNDING contribute positively to the development of } \\
\text { a startup }\end{array}$} \\
\hline & $\begin{array}{l}\text { Strongly } \\
\text { Disagree }\end{array}$ & Disagree & $\begin{array}{l}\text { Neither Agree } \\
\text { nor Disagree }\end{array}$ & Agree & $\begin{array}{l}\text { Strongly } \\
\text { Agree }\end{array}$ \\
\hline \multicolumn{6}{|l|}{$\begin{array}{l}\text { Available funding } \\
\text { opportunities FUN1 }\end{array}$} \\
\hline \multicolumn{6}{|l|}{ Adequate funding received FUN2 } \\
\hline \multicolumn{6}{|l|}{ Access to private funding FUN3 } \\
\hline \multicolumn{6}{|l|}{ Access to public grants FUN4 } \\
\hline $\begin{array}{l}\text { Positive macroeconomic } \\
\text { conditions FUN5 }\end{array}$ & & & & & \\
\hline
\end{tabular}


23. The following factors related to GOVERNMENT/INSTITUTIONAL INTERVENTIONS contribute positively to the development of a startup

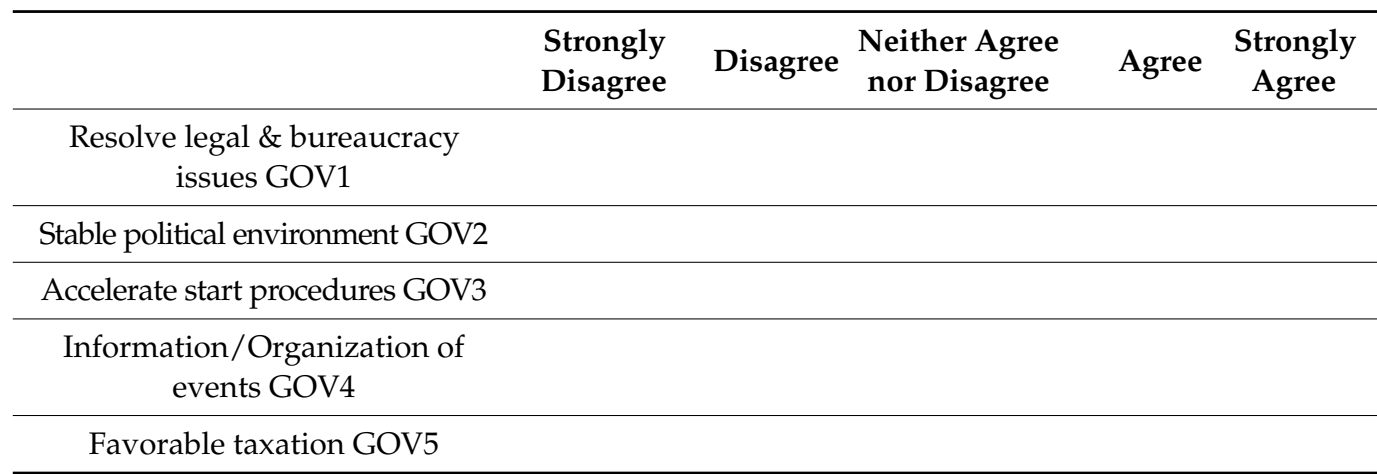

24. The following factors related to SUPPORT/COOPERATION WITH THIRD PARTIES contribute positively to the development of a startup

\begin{tabular}{|c|c|c|c|c|c|}
\hline & $\begin{array}{l}\text { Strongly } \\
\text { Disagree }\end{array}$ & Disagree & $\begin{array}{l}\text { Neither Agree } \\
\text { nor Disagree }\end{array}$ & Agree & $\begin{array}{c}\text { Strongly } \\
\text { Agree }\end{array}$ \\
\hline $\begin{array}{l}\text { Networking with Research } \\
\text { Institutes SUP1 }\end{array}$ & & & & & \\
\hline Networking with Academia SUP2 & & & & & \\
\hline Networking with Incubators SUP3 & & & & & \\
\hline Networking with Industry SUP4 & & & & & \\
\hline $\begin{array}{l}\text { Access to infrastructure and } \\
\text { service providers SUP5 }\end{array}$ & & & & & \\
\hline
\end{tabular}

25. What do you think are the prospects of start-ups in Greece?

\begin{tabular}{lllllll} 
& 1 & 2 & 3 & 4 & 5 & \\
\hline Ominous & & & & & & Auspicious \\
\hline
\end{tabular}

\section{References}

1. Amorós, J.E.; Bosma, N.; Levie, J. Ten Years of Global Entrepreneurship Monitor: Accomplishments and Prospects. Int. J. Entrep. Ventur. 2013, 5, 120-152. [CrossRef]

2. Acs, Z.J.; Szerb, L. Entrepreneurship, Economic Growth and Public Policy. Small Bus. Econ. 2007, 28, 109-122. [CrossRef]

3. Audretsch, D.B. Entrepreneurship Capital and Economic Growth. Oxf. Rev. Econ. Policy 2007, 23, 63-78. [CrossRef]

4. Calvino, F.; Criscuolo, C.; Menon, C. Cross-Country Evidence on Start-up Dynamics. In OECD Science, Technology and Industry Working Papers, No. 2015/06; OECD Publishing: Paris, France, 2015.

5. Ries, E. The Lean Startup: How Today's Entrepreneurs Use Continuous Innovation to Create Radically Successful Businesses; Crown Business: New York, NY, USA, 2011.

6. Bigliardi, B.; Ferraro, G.; Filippelli, S.; Galati, F. The Past, Present and Future of Open Innovation. Eur. J. Innov. Manag. 2021, 24, 1130-1161. [CrossRef]

7. Bigliardi, B.; Ferraro, G.; Filippelli, S.; Galati, F. The Influence of Open Innovation on Firm Performance. Int. J. Eng. Bus. Manag. 2020, 12, 1847979020969545. [CrossRef]

8. Yun, J.J.; Zhao, X.; Jung, K.; Yigitcanlar, T. The Culture for Open Innovation Dynamics. Sustainability 2020, 12, 5076. [CrossRef]

9. Oumlil, R.; Faouzi, H.; Juiz, C. Uncovering Two Decades of Open Innovation Benefits: A Qualitative Meta-Analysis. Int. J. Innov. Technol. Manag. 2020, 17, 2030006. [CrossRef]

10. Spigel, B. The Relational Organization of Entrepreneurial Ecosystems. Entrep. Theory Pract. 2017, 41, 49-72. [CrossRef]

11. Marques, C.S.; Ferreira, J. SME Innovative Capacity, Competitive Advantage and Performance in a'traditional'industrial Region of Portugal. J. Technol. Manag. Innov. 2009, 4, 53-68. [CrossRef]

12. Haltiwanger, J.; Jarmin, R.; Miranda, J. Where Have All the Young Firms Gone? 2012. Available online: https://www.kauffman. org/wp-content/uploads/2019/12/bds_2012.pdf (accessed on 21 June 2020).

13. Adam, F. Introduction. In Measuring National Innovation Performance: The Innovation Union Scoreboard Revisited; Adam, F., Ed.; Springer: Berlin/Heidelberg, Germany, 2014; pp. 1-3. ISBN 978-3-642-39464-5. 
14. Wong, P.K.; Ho, Y.P.; Autio, E. Entrepreneurship, Innovation and Economic Growth: Evidence from GEM Data. Small Bus. Econ. 2005, 24, 335-350. [CrossRef]

15. Audretsch, D.; Keilbach, M. Entrepreneurship Capital and Economic Performance. Reg. Stud. 2004, 38, 949-959. [CrossRef]

16. Fritsch, M. How Does New Business Formation Affect Regional Development? Introduction to the Special Issue. Small Bus. Econ. 2008, 30, 1-14. [CrossRef]

17. Gauthier, J.F.; Penzel, M.; Marmer, M. Global Startup Ecosystem Report 2017. 2017. Available online: https://startupgenome. com/reports/global-startup-ecosystem-report-2017 (accessed on 13 July 2020).

18. Motoyama, Y.; Knowlton, K. Examining the Connections within the Startup Ecosystem: A Case Study of St. Louis. Entrep. Res. J. 2017, 28, 448-470. [CrossRef]

19. Salimath, M.S.; Cullen, J.B. Formal and Informal Institutional Effects on Entrepreneurship: A Synthesis of Nation-Level Research. Int. J. Organ. Anal. 2010, 18, 358-385. [CrossRef]

20. Carlsson, B.; Braunerhjelm, P.; McKelvey, M.; Olofsson, C.; Persson, L.; Ylinenpää, H. The Evolving Domain of Entrepreneurship Research. Small Bus. Econ. 2013, 41, 913-930. [CrossRef]

21. Lee, S.M.; Peterson, S.J. Culture, Entrepreneurial Orientation, and Global Competitiveness. J. World Bus. 2000, 35, 401-416. [CrossRef]

22. Koronios, K.; Kriemadis, A.; Dimitropoulos, P.; Papadopoulos, A. A Values Framework for Measuring the Influence of Ethics and Motivation Regarding the Performance of Employees. Bus. Entrep. J. 2019, 8, 1-19.

23. Ranga, M.; Etzkowitz, H. Triple Helix Systems: An Analytical Framework for Innovation Policy and Practice in the Knowledge Society. In Entrepreneurship and Knowledge Exchange; Routledge: New York, NY, USA, 2015.

24. Etzkowitz, H. Innovation in Innovation: The Triple Helix of University-Industry-Government Relations. Soc. Sci. Inf. 2003, 42, 293-337. [CrossRef]

25. Etzkowitz, H.; Leydesdorff, L. The Triple Helix-University-Industry-Government Relations: A Laboratory for Knowledge Based Economic Development. EASST Rev. 1995, 14, 14-19.

26. Fogelberg, H.; Thorpenberg, S. Regional Innovation Policy and Public-Private Partnership: The Case of Triple Helix Arenas in Western Sweden. Sci. Public Policy 2012, 39, 347-356. [CrossRef]

27. Sarpong, D.; AbdRazak, A.; Alexander, E.; Meissner, D. Organizing Practices of University, Industry and Government That Facilitate (or Impede) the Transition to a Hybrid Triple Helix Model of Innovation. Technol. Forecast. Soc. Chang. 2017, 123, 142-152. [CrossRef]

28. Ranga, L.M.; Miedema, J.; Jorna, R. Enhancing the Innovative Capacity of Small Firms through Triple Helix Interactions: Challenges and Opportunities. Technol. Anal. Strateg. Manag. 2008, 20, 697-716. [CrossRef]

29. Ivanova, I.A.; Leydesdorff, L. Rotational Symmetry and the Transformation of Innovation Systems in a Triple Helix of UniversityIndustry-Government Relations. Technol. Forecast. Soc. Chang. 2014, 86, 143-156. [CrossRef]

30. Bellgardt, F.; Gohlke, J.; Haase, H.; Parzonka, R.; Schicketanz, J. Triple Helix and Residential Development in a Science and Technology Park: The Role of Intermediaries. Triple Helix 2014, 1, 1-14. [CrossRef]

31. Etzkowitz, H.; Zhou, C. Introduction to Special Issue Building the Entrepreneurial University: A Global Perspective. Sci. Public Policy 2008, 35, 627-635. [CrossRef]

32. Carayannis, E.G.; Evans, D.; Hanson, M. A Cross-Cultural Learning Strategy for Entrepreneurship Education: Outline of Key Concepts and Lessons Learned from a Comparative Study of Entrepreneurship Students in France and the US. Technovation 2003, 23, 757-771. [CrossRef]

33. Rodrigues, C.; Melo, A.I. The Triple Helix Model as Inspiration for Local Development Policies: An Experience-Based Perspective. Int. J. Urban Reg. Res. 2013, 37, 1675-1687. [CrossRef]

34. Cooke, P. The Molecular Biology Revolution and the Rise of Bioscience Megacentres in North America and Europe. Environ. Plan. C Gov. Policy 2004, 22, 161-177. [CrossRef]

35. Debackere, K. Managing Academic R\&D as a Business at KU Leuven: Context, Structure and Process. RD Manag. 2000, 30, 323-328.

36. Ranga, M.; Perälampi, J.; Kansikas, J. The New Face of University-Business Cooperation in Finland. Sci. Public Policy 2016, 43, 601-612. [CrossRef]

37. Mets, T.; Andrijevskaja, J.; Varblane, U. The Role of the University of Tartu in the Development of Entrepreneurship in the Region of South Estonia. Int. J. Entrep. Innov. Manag. 2008, 8, 648-664. [CrossRef]

38. Baldini, N. University Patenting and Licensing Activity: A Review of the Literature. Res. Eval. 2006, 15, 197-207. [CrossRef]

39. Carayannis, E.G.; Campbell, D.F. Knowledge Creation, Diffusion, and Use in Innovation Networks and Knowledge Clusters: A Comparative Systems Approach across the United States, Europe, and Asia; Greenwood Publishing Group: Santa Barbara, CA, USA, 2006.

40. Marcovich, A.; Shinn, T. From the Triple Helix to a Quadruple Helix? The Case of Dip-Pen Nanolithography. Minerva 2011, 49, 175-190. [CrossRef]

41. Nyman, G.S. University-Business-Government Collaboration: From Institutes to Platforms and Ecosystems. Triple Helix 2015, 2, 1-20. [CrossRef]

42. Unger, J.M.; Rauch, A.; Frese, M.; Rosenbusch, N. Human Capital and Entrepreneurial Success: A Meta-Analytical Review. J. Bus. Ventur. 2011, 26, 341-358. [CrossRef] 
43. Aspen Network of Development Entrepreneurs. Entrepreneurial Ecosystem Diagnostic Toolkit; Aspen Institute: Washington DC, USA, 2013.

44. Martin, B.C.; McNally, J.J.; Kay, M.J. Examining the Formation of Human Capital in Entrepreneurship: A Meta-Analysis of Entrepreneurship Education Outcomes. J. Bus. Ventur. 2013, 28, 211-224. [CrossRef]

45. Jo, H.; Lee, J. The Relationship between an Entrepreneur's Background and Performance in a New Venture. Technovation 1996, 16, 161-211. [CrossRef]

46. McMullan, W.E.; Gillin, L.M. Industrial Viewpoint-Entrepreneurship Education. Technovation 1998, 18, 275-286. [CrossRef]

47. Helfat, C.E.; Lieberman, M.B. The Birth of Capabilities: Market Entry and the Importance of Pre-History. Ind. Corp. Chang. 2002, 11, 725-760. [CrossRef]

48. Robinson, P.B.; Sexton, E.A. The Effect of Education and Experience on Self-Employment Success. J. Bus. Ventur. 1994, 9, 141-156. [CrossRef]

49. Allen, W.D.; Hall, T.W. Innovation, Managerial Effort, and Start-up Performance. J. Entrep. Finance Bus. Ventur. 2008. [CrossRef]

50. Wadhwa, V.; Holly, K.; Aggarwal, R.; Salkever, A. Anatomy of an Entrepreneur: Family Background and Motivation; Social Science Research Network: Rochester, NY, USA, 2009.

51. Anderson, A.; Li, J. Entrepreneurship and Networked Collaboration; Synergetic Innovation, Knowledge and Uncertainty. J. Gen. Manag. 2014, 40, 7-21. [CrossRef]

52. Chorev, S.; Anderson, A.R. Success in Israeli High-Tech Start-Ups; Critical Factors and Process. Technovation 2006, 26, 162-174. [CrossRef]

53. Dahl, M.S.; Reichstein, T. Are You Experienced? Prior Experience and the Survival of New Organizations. Ind. Innov. 2007, 14, 497-511. [CrossRef]

54. Eckhardt, J.T.; Shane, S.A. Opportunities and Entrepreneurship. J. Manag. 2003, 29, 333-349.

55. Decker, R.; Haltiwanger, J.; Jarmin, R.; Miranda, J. The Role of Entrepreneurship in US Job Creation and Economic Dynamism. J. Econ. Perspect. 2014, 28, 3-24. [CrossRef]

56. Binks, M.R.; Ennew, C.T. Growing Firms and the Credit Constraint. Small Bus. Econ. 1996, 8, 17-25. [CrossRef]

57. Löfsten, H.; Lindelöf, P. Determinants for an Entrepreneurial Milieu: Science Parks and Business Policy in Growing Firms. Technovation 2003, 23, 51-64. [CrossRef]

58. Dimitropoulos, P.; Koronios, K.; Thrassou, A.; Vrontis, D. Cash Holdings, Corporate Performance and Viability of Greek SMEs: Implications for Stakeholder Relationship Management. EuroMed J. Bus. 2019, 15, 333-348. [CrossRef]

59. Stucki, T. Success of Start-up Firms: The Role of Financial Constraints. Ind. Corp. Chang. 2014, 23, 25-64. [CrossRef]

60. Arvanitis, S.; Stucki, T. The Impact of Venture Capital on the Persistence of Innovation Activities of Start-Ups. Small Bus. Econ. 2014, 42, 849-870. [CrossRef]

61. Hsu, D.H. What Do Entrepreneurs Pay for Venture Capital Affiliation? J. Financ. 2004, 59, 1805-1844. [CrossRef]

62. Pratch, L. Value-Added Investing: A Framework for Early Stage Venture Capital Firms. J. Priv. Equity 2005, 8, 13-29. [CrossRef]

63. Dimov, D.; De Clercq, D. Venture Capital Investment Strategy and Portfolio Failure Rate: A Longitudinal Study. Entrep. Theory Pract. 2006, 30, 207-223. [CrossRef]

64. Johnson, W.C.; Sohl, J. Angels and Venture Capitalists in the Initial Public Offering Market. Ventur. Cap. 2012, 14, 27-42. [CrossRef]

65. Madill, J.J.; Haines, G.H.; RIding, A.L. The Role of Angels in Technology SMEs: A Link to Venture Capital. Ventur. Cap. 2005, 7, 107-129. [CrossRef]

66. Festel, G.; Wuermseher, M.; Cattaneo, G. Valuation of Early Stage High-Tech Start-up Companies. Int. J. Bus. 2013, 18, $216-231$.

67. Mazzucato, M. The Entrepreneurial State. Soundings 2011, 49, 131-142. [CrossRef]

68. Mowery, D.C.; Rosenberg, N. Paths of Innovation: Technological Change in 20th-Century America; Cambridge University Press: Cambridge, UK, 1999.

69. Wonglimpiyarat, J. The Dynamic Economic Engine at Silicon Valley and US Government Programmes in Financing Innovations. Technovation 2006, 26, 1081-1089. [CrossRef]

70. Feld, B. Startup Communities: Building an Entrepreneurial Ecosystem in Your City; John Wiley \& Sons: Boca Raton, FL, USA, 2012.

71. Mason, C. Venture Capital in Crisis? Taylor \& Francis: Oxford, UK, 2009.

72. Sternberg, R. Success Factors of University-Spin-Offs: Regional Government Support Programs versus Regional Environment. Technovation 2014, 34, 137-148. [CrossRef]

73. Wang, C.K.; Wong, P.-K. Entrepreneurial Interest of University Students in Singapore. Technovation 2004, 24, 163-172. [CrossRef]

74. Moritz, A.; Block, J.H. Crowdfunding: A Literature Review and Research Directions. In Crowdfunding in Europe; Springer: Cham, Switzerland, 2016; pp. 25-53. [CrossRef]

75. Lechner, C.; Dowling, M. Firm Networks: External Relationships as Sources for the Growth and Competitiveness of Entrepreneurial Firms. Entrep. Reg. Dev. 2003, 15, 1-26. [CrossRef]

76. Walter, A.; Auer, M.; Ritter, T. The Impact of Network Capabilities and Entrepreneurial Orientation on University Spin-off Performance. J. Bus. Ventur. 2006, 21, 541-567. [CrossRef]

77. Mort, G.S.; Weerawardena, J. Networking Capability and International Entrepreneurship: How Networks Function in Australian Born Global Firms. Int. Mark. Rev. 2006, 23, 549-572. [CrossRef]

78. Huang, H.-C.; Lai, M.-C.; Lo, K.-W. Do Founders' Own Resources Matter? The Influence of Business Networks on Start-up Innovation and Performance. Technovation 2012, 32, 316-327. [CrossRef] 
79. Dowling, M.; Helm, R. Product Development Success through Cooperation: A Study of Entrepreneurial Firms. Technovation 2006, 26, 483-488. [CrossRef]

80. Spender, J.-C.; Corvello, V.; Grimaldi, M.; Rippa, P. Startups and Open Innovation: A Review of the Literature. Eur. J. Innov. Manag. 2017, 20, 4-30. [CrossRef]

81. McAdam, M.; McAdam, R. High Tech Start-Ups in University Science Park Incubators: The Relationship between the Start-up's Lifecycle Progression and Use of the Incubator's Resources. Technovation 2008, 28, 277-290. [CrossRef]

82. Aerts, K.; Matthyssens, P.; Vandenbempt, K. Critical Role and Screening Practices of European Business Incubators. Technovation 2007, 27, 254-267. [CrossRef]

83. Grimaldi, R.; Grandi, A. Business Incubators and New Venture Creation: An Assessment of Incubating Models. Technovation 2005, 25, 111-121. [CrossRef]

84. Ratinho, T.; Henriques, E. The Role of Science Parks and Business Incubators in Converging Countries: Evidence from Portugal Technovation 2010, 30, 278-290. [CrossRef]

85. Carayannis, E.G.; Von Zedtwitz, M. Architecting GloCal (Global-Local), Real-Virtual Incubator Networks (G-RVINs) as Catalysts and Accelerators of Entrepreneurship in Transitioning and Developing Economies: Lessons Learned and Best Practices from Current Development and Business Incubation Practices. Technovation 2005, 25, 95-110.

86. Hindle, K.; Yencken, J. Public Research Commercialisation, Entrepreneurship and New Technology Based Firms: An Integrated Model. Technovation 2004, 24, 793-803. [CrossRef]

87. Hurst, E.; Pugsley, B.W. What Do Small Businesses Do? National Bureau of Economic Research: Boston, MA, USA, 2011.

88. Santarelli, E.; Vivarelli, M. Entrepreneurship and the Process of Firms' Entry, Survival and Growth. Ind. Corp. Chang. 2007, 16, 455-488. [CrossRef]

89. Reynolds, P.D.; Camp, S.M.; Bygrave, W.D.; Autio, E.; Hay, M. Global Entrepreneurship Monitor Gem 2001 Summary Report. London Business School \& Babson College. 2002. Available online: https://www.aidaf-ey.unibocconi.it/wps/allegatiCTP/Paul\% 20reynolds\%201.pdf (accessed on 21 June 2020).

90. van der Zwan, P.; Thurik, R.; Verheul, I.; Hessels, J. Factors Influencing the Entrepreneurial Engagement of Opportunity and Necessity Entrepreneurs. Eurasian Bus. Rev. 2016, 6, 273-295. [CrossRef]

91. Caliendo, M.; Kritikos, A.S. "I Want to, but I Also Need to": Start-Ups Resulting from Opportunity and Necessity. In From Industrial Organization to Entrepreneurship; Springer: Bonn, Germany, 2019; pp. 247-265.

92. Hessels, J.; van Gelderen, M.; Thurik, R. Drivers of Entrepreneurial Aspirations at the Country Level: The Role of Start-up Motivations and Social Security. Int. Entrep. Manag. J. 2008, 4, 401-417. [CrossRef]

93. Van der Zwan, P.; Hessels, J. Start-up Motivation and (in) Voluntary Exit. Scales Res. Rep. 2013. Available online: http: / / ondernemerschap.panteia.nl/pdf-ez/h201309.pdf (accessed on 25 August 2021).

94. Chang, S.J. Venture Capital Financing, Strategic Alliances, and the Initial Public Offerings of Internet Startups. J. Bus. Ventur. 2004, 19, 721-741. [CrossRef]

95. Geibel, R.C.; Manickam, M. Comparison of Selected Startup Ecosystems in Germany and in the USA Explorative Analysis of the Startup Environments. GSTF J. Bus. Rev. 2016, 4, 66-71.

96. Kakati, M. Success Criteria in High-Tech New Ventures. Technovation 2003, 23, 447-457. [CrossRef]

97. Song, M.; Podoynitsyna, K.; Van Der Bij, H.; Halman, J.I. Success Factors in New Ventures: A Meta-Analysis. J. Prod. Innov. Manag. 2008, 25, 7-27. [CrossRef]

98. Van Gelderen, M.; Thurik, R.; Bosma, N. Success and Risk Factors in the Pre-Startup Phase. Small Bus. Econ. 2005, 24, 365-380. [CrossRef]

99. Zhang, Y.; Duysters, G.; Cloodt, M. The Role of Entrepreneurship Education as a Predictor of University Students' Entrepreneurial Intention. Int. Entrep. Manag. J. 2014, 10, 623-641. [CrossRef]

100. Hyytinen, A.; Pajarinen, M.; Rouvinen, P. Does Innovativeness Reduce Startup Survival Rates? J. Bus. Ventur. 2015, 30, 564-581. [CrossRef]

101. Aspelund, A.; Berg-Utby, T.; Skjevdal, R. Initial Resources' Influence on New Venture Survival: A Longitudinal Study of New Technology-Based Firms. Technovation 2005, 25, 1337-1347. [CrossRef]

102. Kelley, D.J.; Singer, S.; Herrington, M. Global Entrepreneurship Monitor 2011 Global Report; Global Entrepreneurship Research Association, London Business School: London, UK, 2012.

103. Ahmad, N.; Hoffmann, A. A Framework for Addressing and Measuring Entrepreneurship. In OECD Statistics Working Paper No.2; Organization for Economic Co-Operation and Development (OECD): Paris, France, 2008. Available online: https://ssrn.com/ abstract $=1090374$ (accessed on 18 August 2021).

104. Ács, Z.J.; Szerb, L.; Autio, E. Global Entrepreneurship and Development Index 2011; Springer Internation Publishing: Berlin/Heidelberg, Germany, 2017; Volume 49, pp. 1-10.

105. Jain, R.; Ali, S.W. A Review of Facilitators, Barriers and Gateways to Entrepreneurship: Directions for Future Research. South Asian J. Manag. 2013, 20, 122.

106. Silva, G.M.; Styles, C.; Lages, L.F. Breakthrough Innovation in International Business: The Impact of Tech-Innovation and Market-Innovation on Performance. Int. Bus. Rev. 2017, 26, 391-404. [CrossRef]

107. Li, M.; Jia, S. Resource Orchestration for Innovation: The Dual Role of Information Technology. Technol. Anal. Strateg. Manag. 2018, 30, 1136-1147. [CrossRef] 
108. Neo, B.S. Factors Facilitating the Use of Information Technology for Competitive Advantage: An Exploratory Study. Inf. Manag. 1988, 15, 191-201. [CrossRef]

109. Argote, L.; Ingram, P. Knowledge Transfer: A Basis for Competitive Advantage in Firms. Organ. Behav. Hum. Decis. Process. 2000, 82, 150-169. [CrossRef]

110. Bandera, C.; Thomas, E. Startup Incubators and the Role of Social Capital. In Proceedings of the 2017 IEEE Technology \& Engineering Management Conference (TEMSCON), Santa Clara, CA, USA, 8-10 June 2017; IEEE: Manhattan, NY, USA, 2017; pp. 142-147.

111. Brüderl, J.; Preisendörfer, P. Network Support and the Success of Newly Founded Business. Small Bus. Econ. 1998, 10, $213-225$. [CrossRef]

112. Xiao, L.; North, D. The Graduation Performance of Technology Business Incubators in China's Three Tier Cities: The Role of Incubator Funding, Technical Support, and Entrepreneurial Mentoring. J. Technol. Transf. 2017, 42, 615-634. [CrossRef]

113. Barney, J.B. Organizational Culture: Can It Be a Source of Sustained Competitive Advantage? Acad. Manage. Rev. 1986, 11, 656-665. [CrossRef]

114. Luthans, F.; Avolio, B.J.; Avey, J.B.; Norman, S.M. Positive Psychological Capital: Measurement and Relationship with Performance and Satisfaction. Pers. Psychol. 2007, 60, 541-572. [CrossRef]

115. Luthans, F.; Youssef, C.M. Human, Social, and Now Positive Psychological Capital Management: Investing in People for Competitive Advantage. Organ. Dyn. 2004, 33, 143-160. [CrossRef]

116. Marino, K.E.; De Noble, A.F. Growth and Early Returns in Technology-Based Manufacturing Ventures. J. High Technol. Manag. Res. 1997, 8, 225-242. [CrossRef]

117. Cumming, D.; Walz, U.; Werth, J.C. Entrepreneurial Spawning: Experience, Education, and Exit. Financ. Rev. 2016, 51, 507-525. [CrossRef]

118. Sperandei, S. Understanding Logistic Regression Analysis. Biochem. Med. 2014, 24, 12-18. [CrossRef]

119. Lee, K.; Yoo, J. How Does Open Innovation Lead Competitive Advantage? A Dynamic Capability View Perspective. PLoS ONE 2019, 14, e0223405. [CrossRef]

120. Usman, M.; Vanhaverbeke, W. How Start-Ups Successfully Organize and Manage Open Innovation with Large Companies. Eur. J. Innov. Manag. 2017, 20, 171-186. [CrossRef]

121. Rahman, M.; Rahman, U.H.F.B. How Do Norwegian Technology Start-Ups Use Open Innovation Strategies to Gain Access to New Business Ideas? Open Econ. 2021, 4, 98-105. [CrossRef]

122. Sivam, A.; Dieguez, T.; Ferreira, L.P.; Silva, F.J. Key Settings for Successful Open Innovation Arena. J. Comput. Des. Eng. 2019, 6, 507-515. [CrossRef] 